\title{
Later Zoeal and Early Postlarval Stages of Three Dorippid Species from Japan (Brachyura : Dorippidae : Dorippinae)
}

\section{$\operatorname{AUTHOR}(\mathrm{S}):$}

Quintana, Rodolfo

\section{CITATION:}

Quintana, Rodolfo. Later Zoeal and Early Postlarval Stages of Three Dorippid Species from Japan (Brachyura: Dorippidae : Dorippinae). PUBLICATIONS OF THE SETO MARINE BIOLOGICAL LABORATORY 1987, 32(4-6): 233-274

ISSUE DATE:

1987-12-26

URL:

http://hdl.handle.net/2433/176143

RIGHT: 


\title{
Later Zoeal and Early Postlarval Stages of Three Dorippid Species from Japan (Brachyura : Dorippidae : Dorippinae) ${ }^{1 \text { 1 }}$
}

\author{
By

\section{Rodolfo Quintana} \\ Zoological Institute, Faculty of Science, Hokkaido University, Sapporo 060, Japan
}

With 24 Text-figures and 2 Tables

Previous knowledge of the larval development in dorippid species was summarized by Rice (1980a); all accounts cited by Rice were based entirely on planktonic material. Subsequently an account was published by Terada (1981) who could rear three dorippids (subfamily Dorippinae) through all their zoeal stages. Apart from a brief description of a megalopal stage given by Gilet (1952), there are at present no reports on the early postlarval stages of dorippid crabs. For the present study I could obtain live material of later zoeas of dorippid species which successfully moulted, under laboratory conditions, to the megalopa and subsequently to the first crab stage.

The present paper supplements the previous descriptions of dorippid zoeal stages (Aikawa, 1937; Gilet, 1952; Kurata, 1964; Terada, 1981) by adding details of all appendage structures and scanning electron microscope (SEM) observations, based upon specimens reared in the laboratory. For the first time, it provides observations on the megalopa and first crab stages of three dorippid species of the subfamily Dorippinae inhabiting Japanese waters. A remarkable behaviour exhibited by the megalopa and first crab stages in the laboratory is described and its ecological implications are discussed. Moreover, additional observations on morphological characters of adults of the genera Dorippe, Nobilum and Paradorippe are provided.

\section{Materials and Methods}

The methodology used in this work, including the SEM preparation, is basically the same as that indicated in a previous paper (Quintana, 1986). Later zoeal stages of dorippids were obtained alive from Tosa Bay, Shikoku Island, and maintained in the laboratory in individual compartments. At $28.5-29.7^{\circ} \mathrm{C}$ water temperature and $33.0-33.4 \mathrm{ppt}$ salinity, the larvae successfully moulted to the megalopa and further to the first crab. The names used herein for the present three dorippid species follow the most recent papers on taxonomy within this group, as those of Manning \& Holthuis (1981, 1986) and Holthuis \& Manning (1985). The Japanese and scientific names given by Sakai (1976)

1) Paper presented in the 23rd Annual Meeting of the Japanese Society of Systematic Zoology, Tokyo, Japan, April 1987.

Publ. Seto Mar. Biol. Lab., 32 (4/6), 233-274, 1987.

(Article 8) 
and Miyake (1983) are also noted because these names have been popularly used in Japan. A detailed synonymy can be found in the mentioned accounts. For Dorippe frascone, descriptions are based on zocal stages III and IV, the megalopa, and the first crab stage; for Nobilum japonicum japonicum, on the megalopa and first crab stage, and for Paradorippe granulata, based on zocal stage IV, the megalopa, and the first crab stage. Carapace length of megalopa and first crab was measured from median frontal margin to mid-posterior margin of the carapace. The setation of larval appendages is referred from proximal to distal.

\section{Results}

1. Dorippe frascone (Herbst, 1785)

\section{1-1. Penultimate (=third) Zoea (Figs 1, 3).}

Measurements: Rostral spine length $8.76 \mathrm{~mm}$; dorsal spine length $8.04 \mathrm{~mm}$; distance between tip of rostral spine and tip of dorsal spine $19.75 \mathrm{~mm}$.

Carapace (Figs 1A, 3A): Rostral and dorsal spines extremely long, pointed apically, each about 4.5 times carapace length, extending toward opposite directions in almost straight line, so that the "dorsal" spine is placed on the posterior portion of the carapace; rostral spine finely spinulate along proximal half, and dorsal spine with very minute granules on proximal one-third. No lateral spines. Carapace hardened, posterolateral border fringed with 8 setae.

Antennule (Fig. 1B): Broadened basally, with 5 terminal aesthetascs (the shortest fine), 2 setae and a single subterminal aesthetasc; a fine seta arising opposite to the incipient endopod. Antenna (Fig. 1G): Spinous process with minute spinules on either side of distal half; endopod digitiform, unarmed, about one-fourth length of spinous process; exopod slightly longer than spinous process, with fine spinules densely on distal one-third, and with 2 median spines. Mandible (Fig. 1D): Incisor and molar processes well-developed, toothed; palp absent. Maxillule (Fig. 1E): Endopod indistinctly 2-segmented, devoid of setae proximally, but with 4 setae distally; basal endite unilobed, broad, with 5 serrate spines and 4 fine plumodenticulate setae (total 9); coxal endite with 6 distal setae. Maxilla (Fig. 1F): Endopod elongate, narrow, with 3 terminal, similar setae, and 1 (innermost) longer seta; basal endite broad, bilobed, with 5 setae on each lobe; coxal endite unilobed, slender, with 3 distal setae; scaphognathite fringed with 29-30 plumose setae, posterior lobe rounded marginally. First maxilliped (Fig. IG): Basis with 9 setae along inner margin, arranged 2,2,2,3; endopod 5-segmented, longer than exopod, strongly curved, with 3 setae on the proximal segment and $2,1,2,4+2$ setae on the subsequent segments; exopod 2-segmented, distally with 10 long, plumose setae, of which 2 are medial in position. Second maxilliped (Fig. $1 \mathrm{H}, \mathrm{h}$ ): Basis with a single seta basally; endopod 3-segmented, short, about one-half length of proximal segment of exopod, with no setae on the proximal segment, 1 on the second segment, and $2+1$ setae on the distal segment; exopod 2-segmented, distally with 10 long plumose setae, of which 2 are medial in position. Third maxilliped (Fig. 1I): Rudimentary, biramous, unsegmented.

Pereiopods (Fig. 1J): Rudimentary, visible laterally (together with the third 


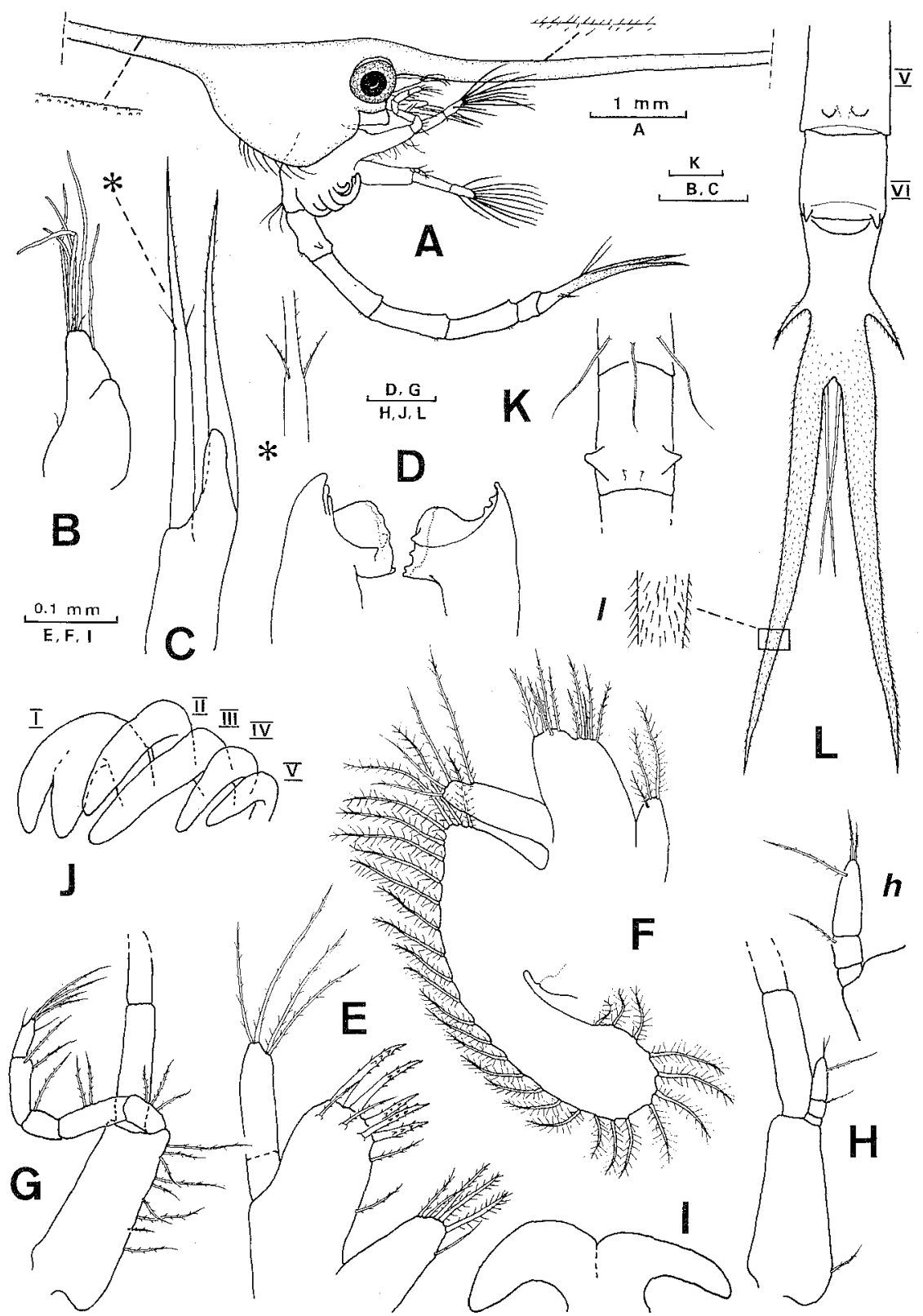

Fig. 1. Dorippe frascone, third zoea. A, zoea, lateral view; B, antennule; C, antenna; D, mandibles; $E$, maxillule; F, maxilla; $G-I$, first to third maxillipeds; $h$, detail of endopod; J, rudiments of pereiopods; $K$, detail of first and second abdominal segments, dorsal view; L, telson, ventral view; 1 , detail of spinulation of furca, as observed by light microscope (compare with Fig. $22 \mathrm{C}$ ). Scale bars $=0.2 \mathrm{~mm}$, except when indicated for $1 \mathrm{~mm}$ and $0.1 \mathrm{~mm}$. 
maxilliped) beneath the zoeal carapace, non functional at this stage; first pereiopod incipiently chelate, 2nd-5th pereiopods unsegmented, digitiform.

Abdomen (Fig. 1A, K): Slender, consisting of 6 segments plus a telson; first somite with 3 long dorsal setae, second somite with 2 short lateral knobs; somites 2-5 each with 2 minute setae dorsally; somites 3-5 elongated, about 4 times as long as broad, sixth somite short, as long as broad, with 2 short truncate projections lateroventrally. Pleopods absent at this stage, although indistinct ventral protuberances can be observed on somites 2-5. Telson (Fig. 1L): Elongate, proximal portion medially constricted and armed with 2 stout lateral spines, which are obliquely directed; each spine as long as the narrowest width of the telson. Furcae very long, divergent posteriorly, with no outer spines; maximum width (at tips) 1.26 times the maximum distance between the lateral spines of the telson; 2 long, inner setae arising proximally, reaching nearly one-half of furcal length. Telson evenly spinulose from lateral spines to tips of furcae.

\section{1-2. Last (=fourth) Zoea (Figs 2, 22).}

Measurements: Length of rostral spine $11.76 \mathrm{~mm}$; length of dorsal spine 11.5 $\mathrm{mm}$, distance between tip of rostral spine and tip of dorsal spine $24.7 \mathrm{~mm}$.

Carapace (not drawn): Rostral and dorsal (=-posterior) spines extremely long; lateral spines absent; posterolateral borders of carapace fringed with 21-23 setae.

Antennule (Fig. 2A): Somewhat inflated basally, with 2-3 setae proximally; endopod longer than in previous stage, unsegmented, unarmed; aesthetascs arranged into three groups, namely, a single aesthetasc proximally, a medial group of 9 aesthetascs, and a distal group of 4 aesthetascs plus an outer seta. Antenna (Fig. 2B): Exopod slightly longer than the spinous process, with 2 prominent setae on the distal one-third; endopod now longer than one-half of spinous process. Mandible (not drawn): Incisor and molar processes strong, more toothed than in previous stage; palp absent. Maxillule (Fig. 2C): Endopod clearly 2-segmented, proximal segment devoid of setae, distal segment with 4 terminal setae; basal endite with 11 setae-spines; coxal nedite with 6-7 setae. Maxilla (Fig. 2D): Endopod with 4 setae distally; basal endite bilobed, with $6+6$ setae on each lobe; coxal endite reduced, with 3 distal setae; scaphognathite fringed with 49 plumose setae. First maxilliped (not drawn): Basis with 9 marginal setae, arranged 2,2,2,3; endopod 5segmented, with 3 setae on the proximal segment and $2,1,2,4+2$ setae on the subsequent segments; exopod with 14 plumose setae on distal segment, of which one pair is subterminal and another proximal in position. Second maxilliped (not drawn): Basis with 2 setae proximally; endopod short, 3-segmented, with no setae on the proximal segment, 1 on the second, and $2+1$ setae on the distal segment; exopod with 13-14 long plumose setae on distal segment, of which one pair is medial, and another pair is rather proximal in position. Third maxilliped and pereiopods (not drawn): Still rudimentary but more developed than in the previous stage, non functional.

Abdomen (Fig. 2E-G): Pair of posterolateral setae of the first segment not 


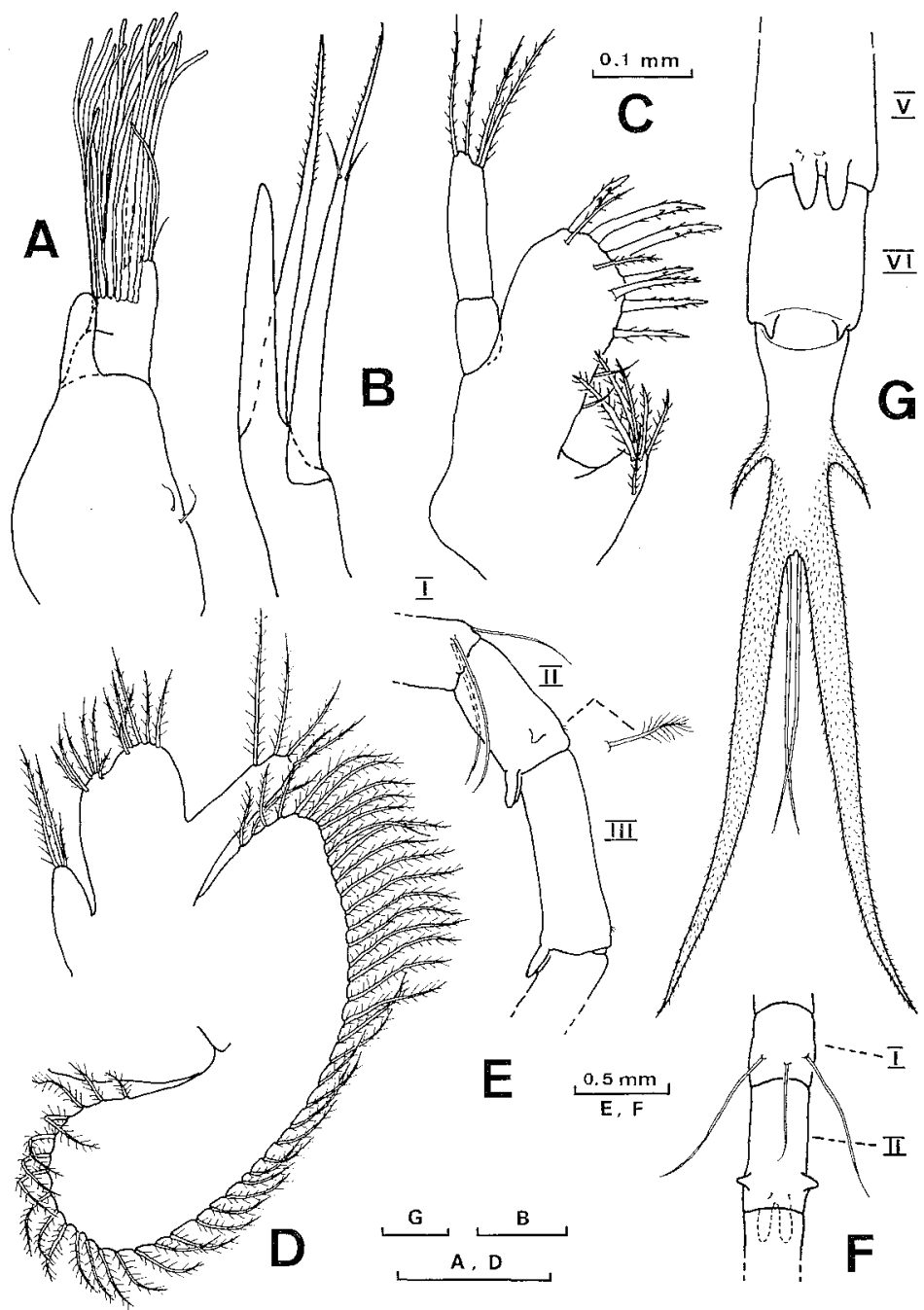

Fig. 2. Dorippe frascone, fourth zoea. A, antennule; B, antenna; G, maxillule; D, maxilla; E, abdominal segments $1-3$, lateral view; $F$, first and second segments, dorsal view; $G$, telson and posterior two abdominal segments. Scale bars $=0.2 \mathrm{~mm}$, except for $\mathrm{C}, \mathrm{E}, \mathrm{F}$.

reaching the posterior margin of the second segment. Pleopods developed as buds on the segments 2-5; armature and setation as in the previous stage. Telson (Fig. 2G): More divergent distally; inner setae slightly longer than one-half of furcal length; fine spinulation evenly covering from lateral spines of telson to tips of furcae. Maximum width of furcae (at tips) now is 1.9-2.2 times the maximum distance between the tips of lateral spines of the telson.

\section{1-3. Megalopa (Figs 3-5, 23).}

Measurements: Carapace length $2.94 \mathrm{~mm}$; maximum carapace width $2.68 \mathrm{~mm}$.

Carapace (Fig. 3B, G): Longer than broad, subquadrate, invested with numerous setae of varying lengths and sparse spinules, unevenly on lateral margins. Front 
broad medially depressed, slightly projected anteriorly, bilobed; each lobe minutely crenulate distally. Anterolateral borders projected as strong teeth, each pointed, curved at tips finely spinulate on inner margin. Distance between tips of external orbital teeth shorter than maximum width. Orbits broad obtuse; orbital fissure

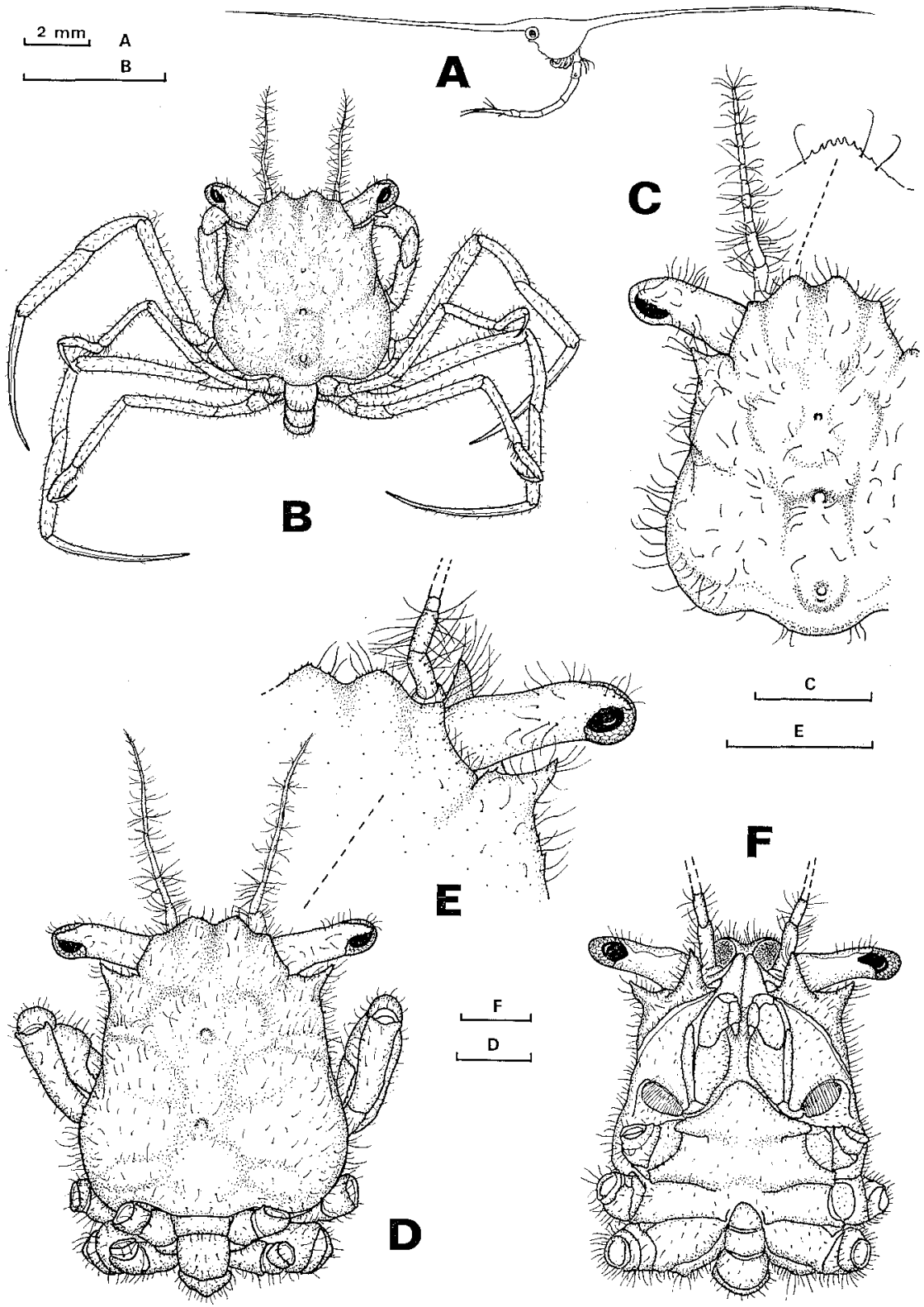

Fig. 3. Dorippe frascone. Zoea (A), megalopa (B, C) and first crab (D-F) stages. A, third zoea, lateral view; B, megalopa, complete specimen, dorsal view; C, carapace, dorsal view, and a detail of frontal lobe; $\mathrm{D}$, first crab, dorsal view; E, detail of frontoorbital region; $F$, carapace, ventral view. Scale bars $=1 \mathrm{~mm}$, except for $A$ and $B$. 
distinct short. Eyes large extending laterally beyond outermost carapace margin; ocular peduncle setose. Regions not clearly defined at this stage; cardiac region somewhat swollen, metabranchial region expanded laterally; a mid-dorsal tubercle present on mesogastric, cardiac and intestinal regions.

Antennule (Fig. 4A, a): Considerably modified from previous stage, with a distinct peduncle and a pair of flagella. Peduncle 3-segmented: basal segment globose, setose proximally; second segment elongate, sparsely setose; distal segment broader distally, invested with some setae, slightly bifurcated. Outer flagellum broad, 4-segmented: proximal segment devoid of aesthetascs; segments 2-4 each with numerous aesthetascs and an additional short outer seta on segment 2 and 3; 2 long, apical setae on the fourth segment. Inner flagellum slender, unsegmented, armed with 6 terminal and $2+1$ subterminal setae. Antenna (Fig. 4B): Peduncle 3-segmented, not covered with tomentum but invested with long setae, most numerous on distal segment; basal segment with spinules on margin and 2 protuberances distally; flagellum 11-segmented, each segment (except the basal) armed with long setae, often 2-4 times longer than the respective segment. Mandibles (Fig. 4C, c): Asymmetrical, slightly different. Mandibular plate hard, broadly expanded; cutting edge spade-shaped, pointed medially (the another mandible in a same specimen is not medially produced), armed with minute indentation along inner distal margin. Palp 3-segmented, with 0,0,11 setae. Maxillule (Fig. 4D): Endopod 2-segmented, distal segment strongly flected, with 7 setae on basal segment and 1 proximal and 4 terminal setae on distal segment; basal endite with 35 setae-spines, of which a group of 5 setae is inner-proximal in position; coxal endite with 15 setae. Outer margin of basal endite with a single plumose seta. Maxilla (Fig. 4E): Endopod unilobed, broad basally, with 5 distal setae; basal endite bilobed, broad distally, with 25 setae in total (10 on proximal lobe and 15 on distal lobe); coxal endite reduced, unilobed, with 3 terminal setae; scaphognathite broadly expanded, fringed with 105-108 plumose setae. First maxilliped (Fig. 4F): Endopod lanceolate, greatly developed, with more than one-half of its length free in normal position, distal margin truncate, fringed with numerous setae along entire margins; basal and coxal endites entire, each with numerous setae; exopod 2-segmented, proximal segment elongate, with 4 outer distal setae, distal segment (=flagellum) strongly flected, armed with 14 plumose setae. Epipod broad basally, unarmed. Second maxilliped (Fig. 5A): Endopod 5-segmented, distal segments with rigid setae and spines. Exopod 2-segmented; proximal segment with 3 outer distal setae and a single seta on inner margin, distal segment with 9-10 plumose, terminal setae. Epipod reduced, digitiform, with 4 setae on basis. Third maxilliped (Fig. 5B): Endopod 5-segmented, all profusely setose on surface and margins, merus with a strong acute projection on inner median border. Exopod with no distal flagellum; the single segment reaching near the half of merus, armed with 3 distal setae and an additional proximal seta. Epipod basally triangular, elongate distally, with 3-4 rows of plumose setae on basis and 32-33 long naked setae.

Pereiopods (Figs 5 I-M, m, 23A-D): All well-developed, profusely setose, without 
granules or spines, and evenly covered with a fine tomentum. Chelipeds almost equal in size, in setation and in dentition of fingers, reduced, shorter than the carapace; carpus and palm with short setae; merus more setose; inner borders of fingers with 10-12 teeth. Second and third ambulatory legs evidently longer than carapace,

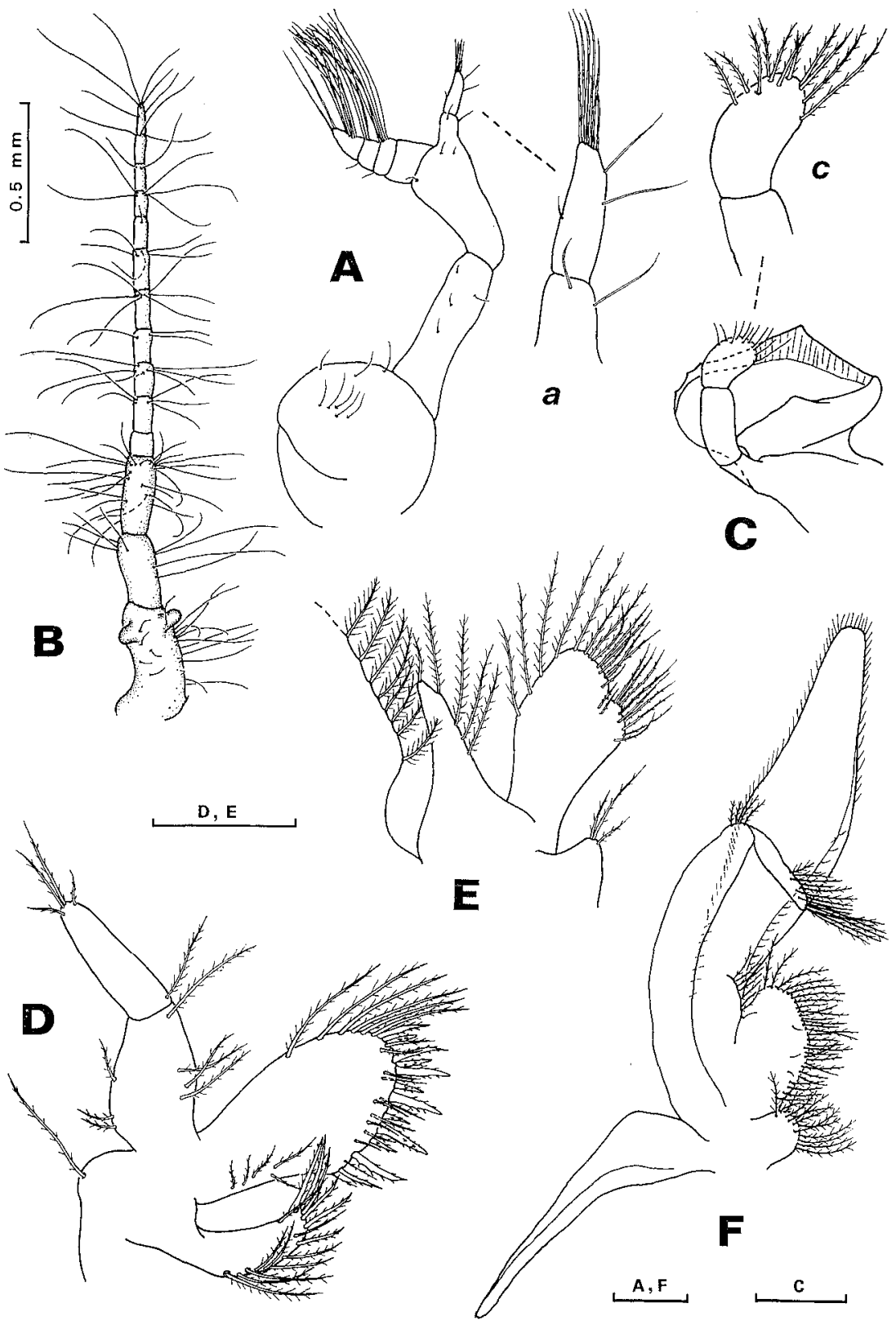

Fig. 4. Dorippe frascone, megalopa. A, antennule; a, detail of inner flagellum; B, antenna; $\mathrm{C}$, mandible; c, detail of distal segment of palp; D, maxillule; E, maxilla (scaphognathite partially drawn); F, first maxilliped. Scale bars $=0.2 \mathrm{~mm}$, except for $\mathrm{B}$. 
third leg longer than the second, both very similar in morphology; dactylus narrow, flattened, slightly curved, pointed distally, almost as long as propodus + carpus. Last two pairs of pereiopods slightly longer than carapace and more slender and shorter than pereiopods 2 and 3 , distinctly subchelate; dactylus conical, closing

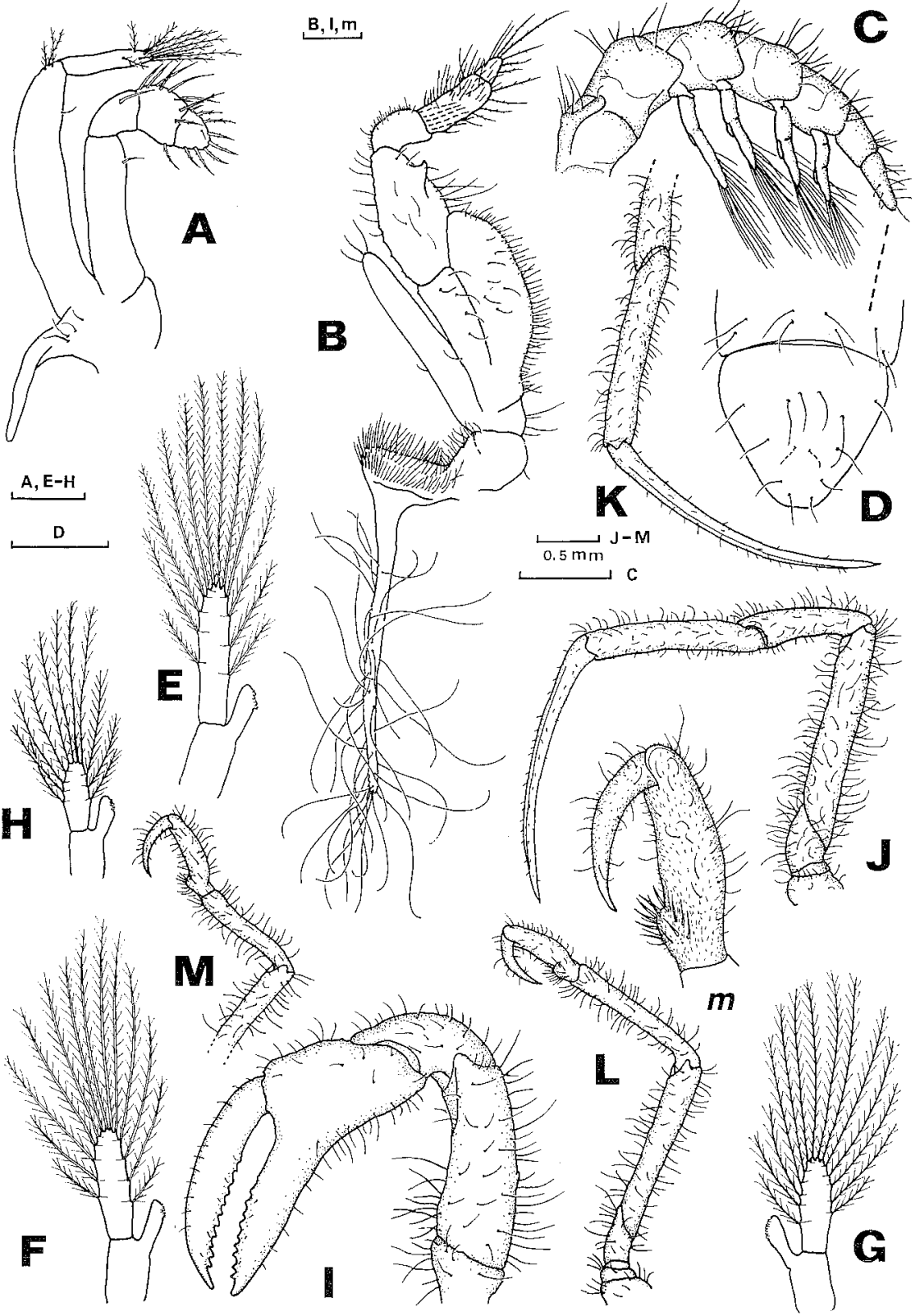

Fig. 5. Dorippe frascone, megalopa. A, second maxilliped; B, third maxilliped; C, abdomen, lateral view; D, telson, dorsal view; E-H, first to fourth pleopods; I-M, pereiopods $1-5 ; \mathrm{m}$, detail of propodus and dactylus of the fifth pereiopod. Scale bars $=0.2 \mathrm{~mm}$, except when indicated for $0.5 \mathrm{~mm}$. 
against a proximal spinose-setose prominence on propodus; dactylus and propodus curved, shorter than carpus. Dactylus not opening beyond 90 degrees due to a hinge-like projection on the inner proximal portion, locking against the expanded and rounded inner distal projection of propodus; outer distal margin of propodus always shorter than the inner margin.

Abdomen (Fig. 5G): Subcylindrical, consisting of 6 segments plus the telson, armed with dorsal and lateral setae on all segments. Pleopods (Fig. 5E-H) welldeveloped, present on segments 2-5; no uropods. First pleopod with 12 long plumose setae on exopod and 9 small hooked setae on endopod; second pleopod with 12-13 long plumose setae and 9 hooked setae; third pleopod with 13-14 plumose setae and 7-8 hooked setae; fourth (last pleopod with 11 plumose setae and 9-10 hooked setae. Telson (Fig. 5D): Somewhat flattened, longer than the sixth abdominal segment, broadly triangular, rounded marginally; basal portion equal to its length. Telson invested with 12 setae dorsally and 2 on ventral surface.

\section{1-4. First crab (Figs 3, 6, 7, 24).}

Measurements: Carapace length $3.79 \mathrm{~mm}$; maximum carapace width $3.53 \mathrm{~mm}$.

Carapace (Fig. 3D, E): Subquadrate, longer than broad, narrowing anteriorly. The general morphology of the carapace closely resembles that of the megalopa. Abdomen not perfectly flected beneath the carapace; proximal abdominal somites 1-3 and coxae of pereiopods 2-5 visible in dorsal view. Margins of carapace with minute spinules, front medially depressed, with finely crenulate lobes. Orbits slightly obtuse. Eyes projected laterally, surpassing the outermost margin of carapace. Regions more defined than in the previous stage, although carapace grooves not distinct; dorsal protuberances on gastric and cardiac regions. Sternum (Fig. 3F): Free portion of the endopod of first maxillipeds produced anteriorly to form an elongated, rather smooth, triangular plate, not reaching the frontal notch; epistome reduced. Suborbital spines greatly developed, directed forward, extending to nearly same level of tips of first maxillipeds. External (=third) maxillipeds relatively short, reaching anteriorly the pterygostomial groove, which runs broadly as an arch. Afferent branchial openings large, oval, obliquely placed in front of the bases of external maxillipeds, and fringed with numerous straight and rigid setae. Abdomen partially flected, reaching anteriorly the midpoint of the second thoracic sternite. Sternum without granules or spinules, but evenly setose.

Antennule (Fig. 6A, a, $\mathrm{a}_{\mathbf{1}}$ ): Basal segment globose, setose; outer flagellum normally 6 -segmented, with $0,12,10,8,5,2$ aesthetascs plus additional setae, occasionally with 7 segments (for a case of individual variation see Fig. 6A, a). Inner flagellum 3 -segmented, with no setae on the proximal segment, 1 on the second, and 8 setae on the distal segment. Antenna (Fig. 6B, b): With a 3-segmented peduncle, each segment invested with long setae; basal segment with minute spinules. Flagellum with 16 segments, each (except the basal) invested with long and additional shorter setae. Mandibles (Fig. 6C, c): Slightly asymmetrical, and somewhat different in dentition of cutting edge; distal segment of the 3-segmented palp with 15 setae. 
Maxillule (Fig. 6D): Endopod 2-segmented, strongly flected, with 6 and 2 setae on the proximal and distal segments respectively; basal endite with 40 setae-spines; coxal endite curved anteriorly, with 18-19 setae. Outer margin of basal endite with a single seta. Maxilla (Fig. 6E, e): Endopod broad basally, with 4 setae on

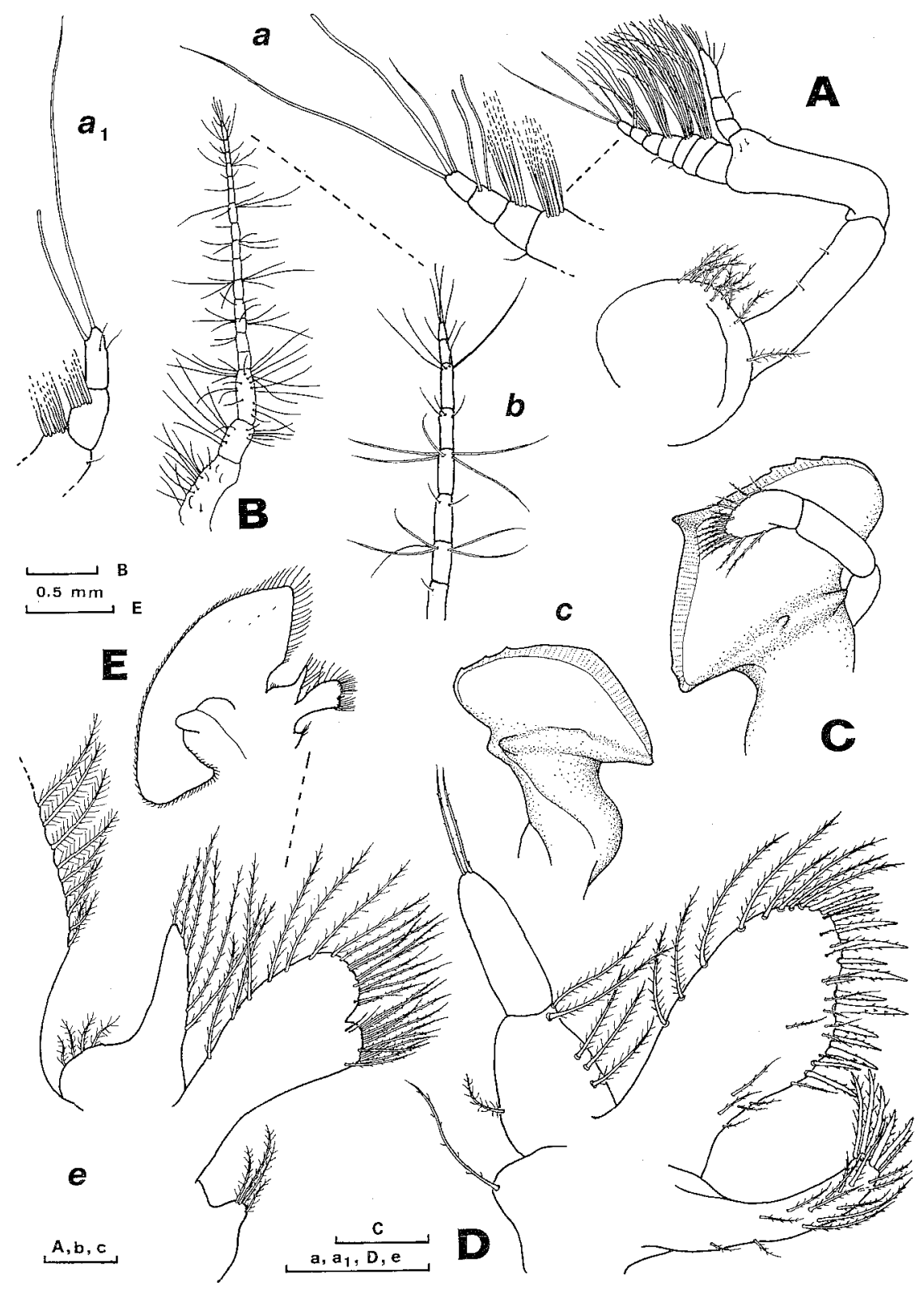

Fig. 6. Dorippe frascone, first crab. A, antennule; $a, a_{1}$, details of apical segments of outer flagellum; $B$, antenna; $b$, detail of distal segments; $C, c$, mandibles, inner view (in $c$, palp has been omitted); D, maxillule; $\mathrm{E}$, maxilla, complete; $\mathrm{e}$, detail of inner endites. Scale bars $=0.2 \mathrm{~mm}$, except for $\mathrm{B}$ and $\mathrm{E}$. 
outer basal margin and 6 longer setae on inner margin; basal endite bilobed, with 13 and 17 setae on the proximal and distal lobes respectively; setae of proximal lobe all fine and terminal in position. Coxal endite reduced, with 3-4 terminal setae. Scaphognathite fringed with $148-150$ plumose setae, of which the longer ones are

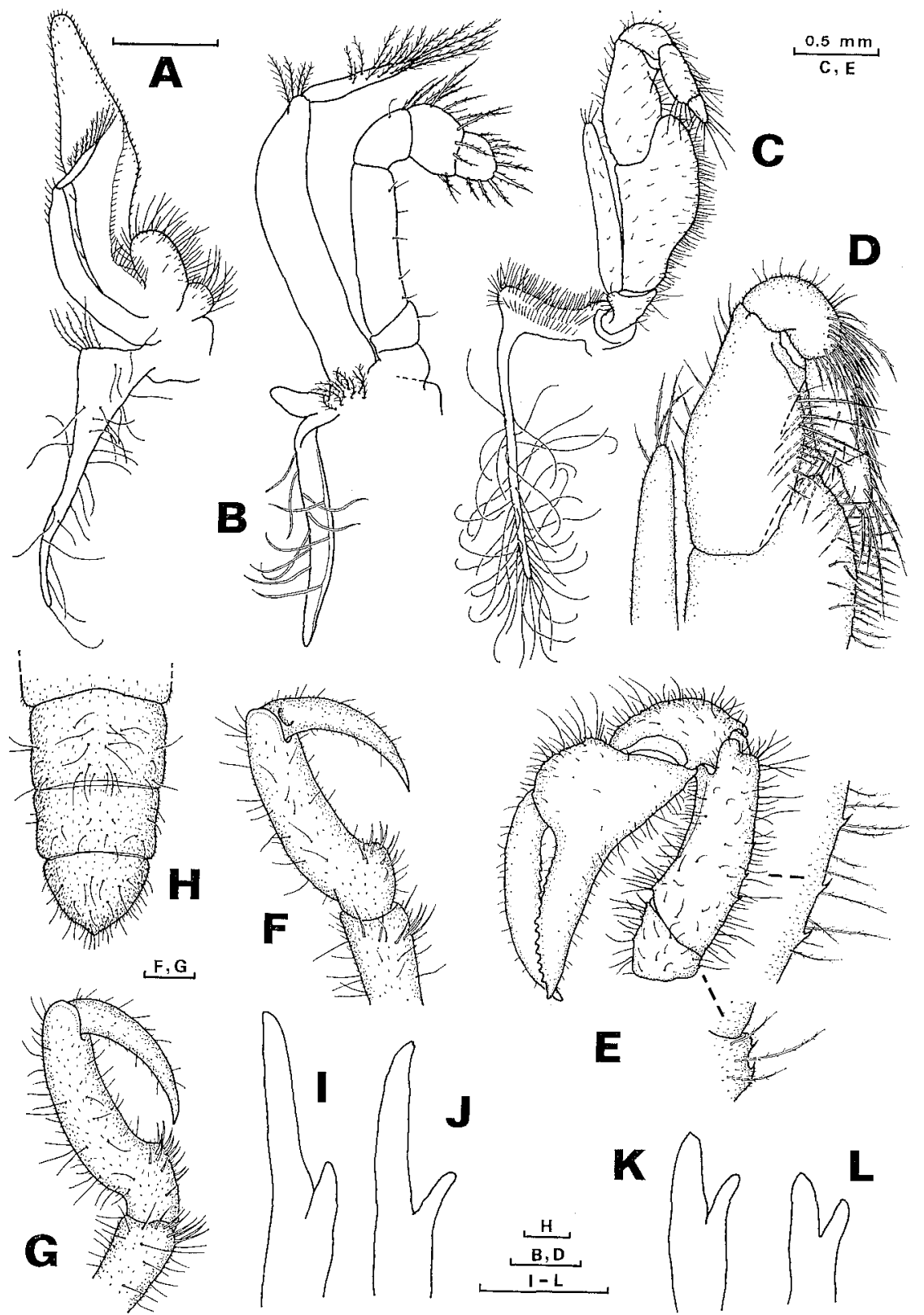

Fig. 7. Dorippe frascone, first crab. A-C, first to third maxillipeds; D, distal half of third maxilliped, ventral view; E, cheliped; F, G, apical details of fourth and fifth pereiopods respectively; $\mathrm{H}$, abdomen, dorsal view; I-L, first to fifth pleopods. Scale bars $=0.2$ $\mathrm{mm}$, except for $\mathbf{C}$ and $\mathbf{E}$. 
placed anteriorly; additional minute setae on surface. First maxilliped (Fig. 7A): Endopod large, elongate, armed with many short setae on margins and distal surface; inner distal margin almost straight, outer proximal margin devoid of setae and somewhat curved to accommodate the long basal segment of the exopod; basal and coxal endites profusely setose on margins and surface; exopod with 6-7 disto-external setae on basal segment, and 12-13 plumose setae on distal segment. Epipod with a group of 5-6 outer proximal setae and 25 naked setae. Second maxilliped (Fig. 7B): Exopod 2-segmented, basal segment with no marginal setae, but 4 plumose setae disto-externally, distal segment with 14 plumose setae. Epipod with 10 naked setae; a short podobranch (=gill) attached basally to epipod, and a group of 10-11 plumose setae proximally. Third maxilliped (Fig. 7C, D): Profusely setose and finely pubescent (=tomentose) on endo- and exopod. Epipod more elongate basally than in the previous stage, profusely setose, with 38-40 long naked setae on its distal half.

Pereiopods (Figs 7E-G, 24A): General morphology closely resembling that of megalopa. Chelipeds very similar, shorter than carapace, all segments tomentose except the palm; margins of ischium and merus with minute spines; fingers distinctly toothed. Pereiopods 2-3 (not drawn) long; dactyli long, flattened, acute distally, slightly twisted. Last two pairs of pereiopods shorter, normally flected and subdorsal in position; rigid setae on distal inner margin of carpus, and rigid setaespines on the basal elevation of propodus; dactylus conical, tip smooth.

Abdomen (Fig. 7H) : Dorso-ventrally flattened, consisting of 6 segments plus the telson, evenly covered with a fine tomentum; each somite evidently broader than long, invested with many setae dorsally. Pleopods (Fig. 7I-L) on segments 2-5, each biramous, unarmed; exopod long, decreasing in size on successive pleopods. Telson (Fig. 7H): Broader than long, convergent posteriorly, acuminate medially, setose dorsally.

\section{1-5. Remarks.}

Names previously used in Japan: Dorippe dorsipes (L.) sensu Miers, 1844; Dorippe (Dorifpe) frascone (Herbst, 1785).

Japanese name: Kimen-gani.

The megalopa of this species remained for 10 days before moulting to the first crab stage; the shortest duration was one week, recorded in two individuals. No data could be obtained for the duration of the first crab stage. Both the megalopa and the first crab stages observed in the laboratory normally used their fourth and fifth pereiopods to carry small objects dorsally over the carapace, so they were not active swimmers.

\section{Nobilum japonicum japonicum (Von Siebold, 1824)}

\section{2-1. Megalopa (Figs 8-10).}

Measurements: Carapace length $2.76 \mathrm{~mm}$; carapace width $2.65 \mathrm{~mm}$.

Carapace (Fig. 8A, B): Longer than broad, narrowing anteriorly, rather flattened 
dorsally, regions moderately demarcated; surface completely covered with a fine tomentum, sparsely with setae, more setose along borders, no granules or spines. Front broad, projected into 2 lobes, margins expanded laterally. Outer-orbital teeth acuminate distally. Ocular peduncle short, finely tomentose, setose distally. Eyes

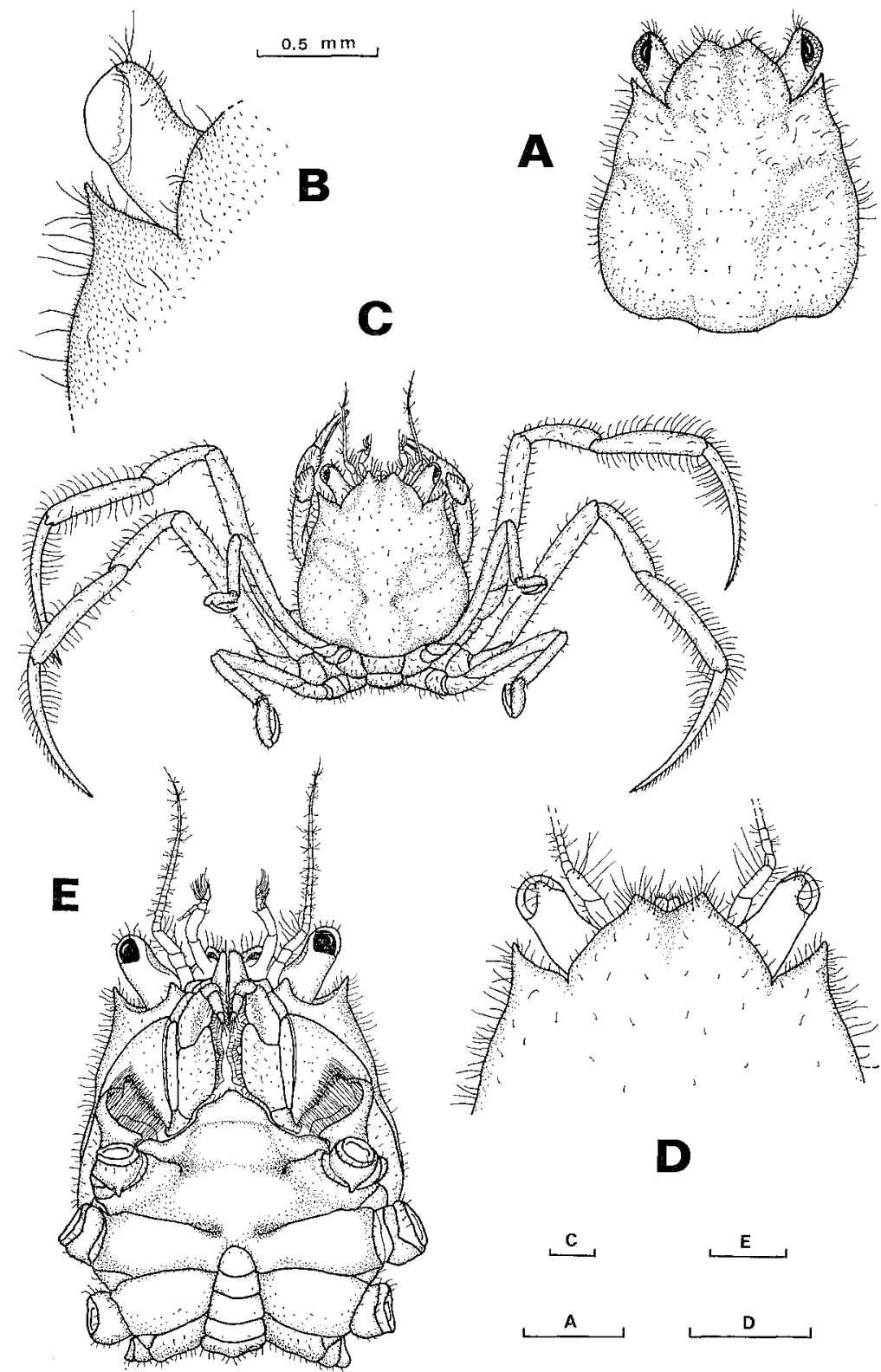

Fig. 8. Nobilum japonicum japonicum. Megalopa (A, B) and first crab (C-E) stages. A, carapace, dorsal view; $\mathrm{B}$, fronto-orbital region, dorsal view; $\mathrm{C}$, first $\mathrm{crab}$, complete specimen, dorsal view; $\mathrm{D}$, anterior portion of carapace, dorsal view (antennules omitted); $\mathrm{E}$, ventral view. Scale bars $=1 \mathrm{~mm}$, except $B$. 
extending obliquely to nearly the same level of anterolateral teeth, and evidently shorter than maximum carapace width. Proximal segments of abdomen and coxae of pereiopods 2-5 visible dorsally.

Antennule (Fig. 9A): Peduncle 3-segmented, greatly tomentose from proximal segment to proximal half of the distal segment; basal segment globose, setose. Outer flagellum 4-segmented, with tiers of aesthetascs in all segments except the proximal one, arranged as 7,6,4 aesthetascs; third segment with 3 additional short setae; apical segment with 2 long, unequal setae. Inner flagellum 2-segmented, with 2 and 7 setae on the proximal and distal segments respectively. Antenna (Fig. 9B): Peduncle and flagellum greatly tomentose; peduncle 3-segmented, sparsely setose, with 2 distal protuberances on basal segment; flagellum composed of 14 segments, each (except the basal one) armed with setae, those on proximal segments shorter than those on the distal segments. Mandibles (Fig. 9C, $\mathrm{C}_{1}, \mathrm{c}$ ): Asymmetrical, slightly different in setal armature and shape of cutting edge. Cutting edge broadly triangular, spade-shape. Palp 3-segmented, with setae only on the distal segment: 11 setae in the left mandible (having cutting edge pointed medially), and 13 setae on the right mandible (not pointed medially). Maxillule (Fig. 9D): Endopod strongly flected, 2-segmented, each with 2 setae distally; basal endite with 29-31 setae-spines, some short setae placed proximally; coxal endite with 15-16 setae-spines. Maxilla (Fig. 9E, e): Endopod digitiform on distal half, with 3 setae on proximal outer border and 2 subterminal setae; basal endite bilobed, with 16 setae in total $(8+8)$; coxal endite greatly reduced, with 2 short apical setae; scaphognathite fringed with 110-113 setae, the longer ones placed toward anterior lobe; additional short setae on surface. First maxilliped (Fig. 9F): Endopod elongate, setose on margins and tomentose on distal half; basal endite oval, non-tomentose, with long setae marginally and shorter setae on surface; coxal endite small, tomentose, invested with numerous setae; exopod armed with a single median seta and 4 distal setae on its basal segment and 12 plumose setae on its distal segment. Epipod with a single seta proximally. Second maxilliped (Fig. 10A): Endopod 5-segmented, with spines and rigid setae on distal segments; second segment with a minute spine on inner margin, as illustrated. Exopod with a single seta medially and 3-4 setae apically on the proximal segment, and 10 plumose setae on distal segment. Epipod short, digitiform, unarmed; podobranch (=gill) vestigial. Third maxilliped (Fig. 10B): All surface, except the epipod, covered uniformly with a fine tomentum; endopod profusely setose, with a stout projection on inner margin of merus; exopod unisegmented, slender, rounded at tip, setose. Epipod with broad base, invested with 3-4 transverse rows of rigid setae, and 26 long naked setae on the distal $3 / 4$.

Pereiopods (Fig. 10G-F): All profusely tomentose. Chelipeds similar, setose, with no granules or spines, except 3 minute spines on inner proximal margin of merus (not observable in figure); cutting edge of fingers strongly armed with acute teeth along entire length. Second and third pereiopods similar, setose, finely tomentose in all segments except on distal half of dactylus; dactylus long, flattened, setose marginally. Pereiopods $4-5$ shorter than pereiopods $2-3$, highly tomentose; propodus 
and dactylus short, both often flected; dactylus conical, closing against the propodus, reaching the inner proximal protuberance of propodus; the inner proximal protuberance of propodus highly setose and spinous.

Abdomen (not drawn): Subcylindrical, consisting of 6 segments plus the telson,

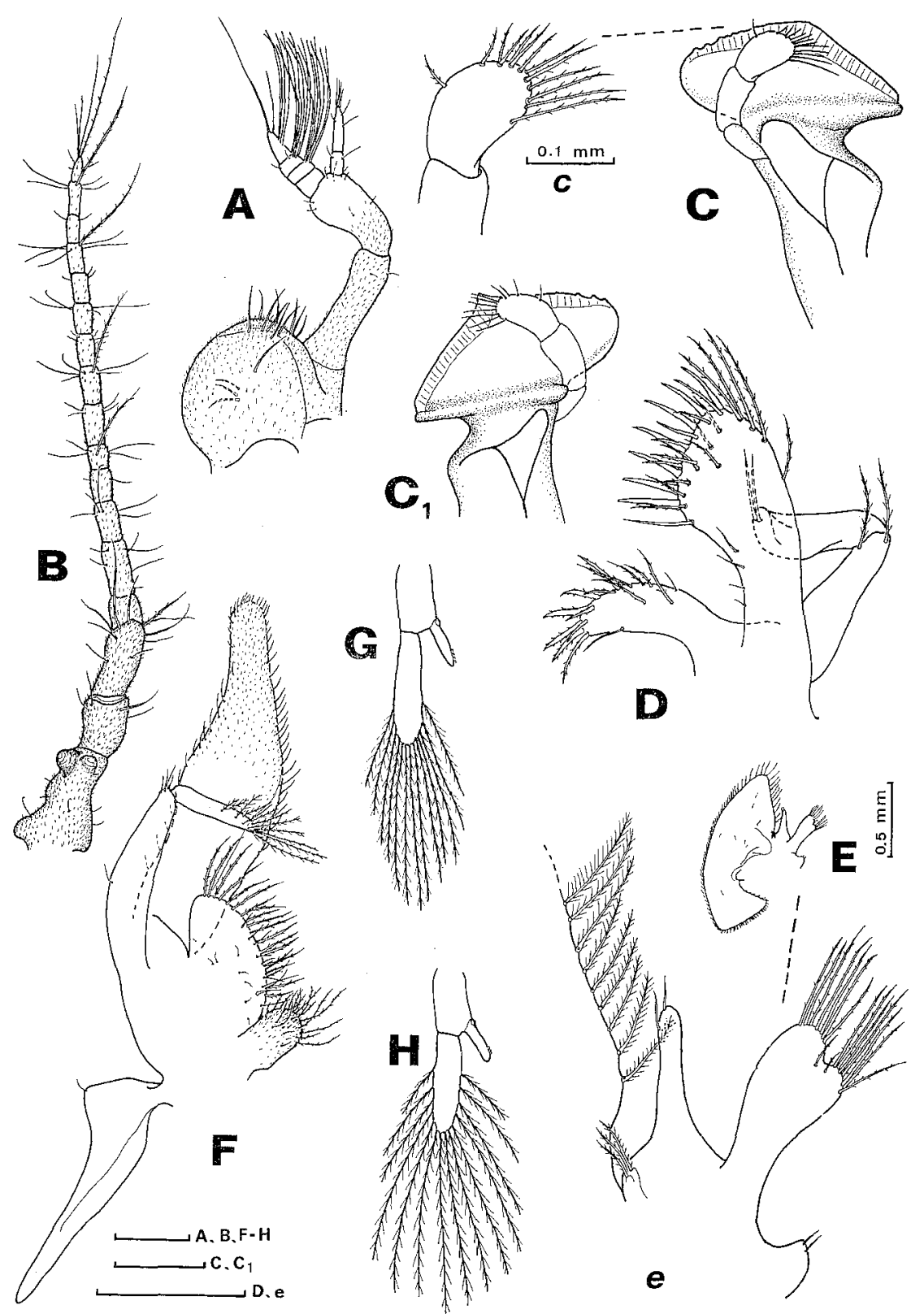

Fig. 9. Nobilum japonicum japonicum, megalopa. A, antennule; $\mathrm{B}$, antenna; $\mathrm{C}, \mathrm{C}_{1}$, right and left mandibles (c, distal segment of palp); D, maxilhule; $\mathrm{E}$, maxilla, complete; e, inner endites; F, first maxilliped; G, second pleopod; H, third pleopod. Scale bars $=0.2$ $\mathrm{mm}$, except for $\mathrm{c}$ and $\mathrm{E}$. 
uniformly covered with a fine tomentum and sparse setae. Pleopods present on segments 2-5, slightly different in setation: second pleopod with 12-13 long plumose setae on the exopod and 7-9 short hocked setae on endopod; third pleopod with 13-14 long exopodal setac and 8-9 short hooked setae on endopod (Fig. 9G, H).

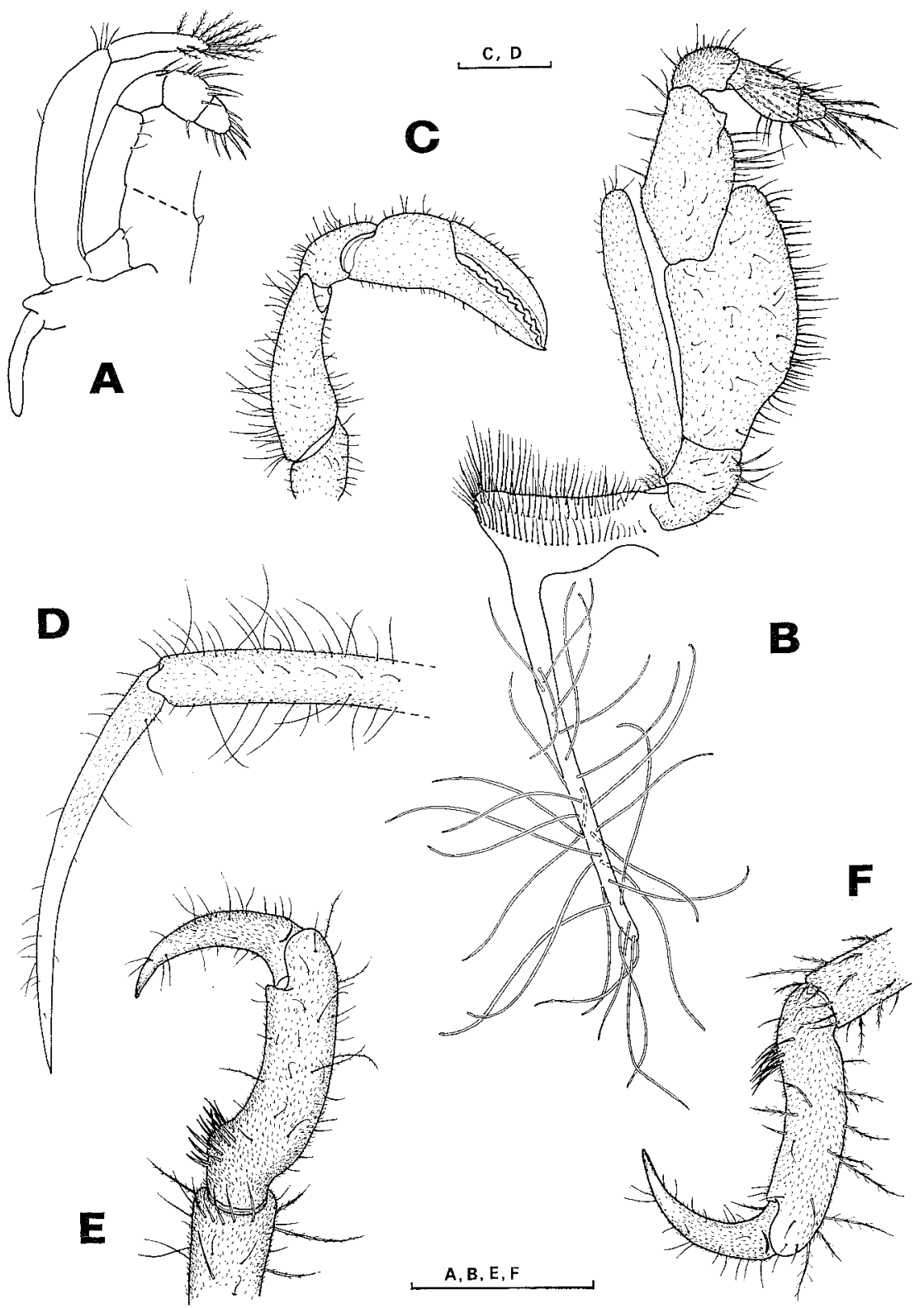

Fig. 10. Nobilum japonicum japonicum, megalopa. A, second maxilliped; B, third maxilliped; $\mathrm{C}$, cheliped; D, third pereiopod, distal portion; E, fourth pereiopod, distal portion; F, fifth pereiopod, distal portion. Scale bars $=0.5 \mathrm{~mm}$. 


\section{2-2. First Crab (Figs 8, 11, 12, 24).}

Measurements: Carapace length $3.94 \mathrm{~mm}$; maximum carapace width $3.88 \mathrm{~mm}$.

Carapace (Fig. 8C, D): Very similar to that of the megalopa, slightly longer than broad, with no granules or spines; endostome (mouth field) visible dorsally, projecting beneath the median frontal sinus. Front somewhat depressed medially, invested with long setae marginally; orbits clearly obtuse. Eyes obliquely directed, not reaching the tips of outer-orbital teeth. Two oblique, oval epibranchial areas visible dorsally; cardiac region also demarcated; coxae of pereiopods 3-5 and proximal segments 1-2 of the abdomen visible in dorsal view. Sternum (Fig. 8E): Endopod of first maxillipeds reaching slightly farther forwards than median frontal sinus. Suborbital spines reduced, smooth, extending to nearly the same level of the outer-orbital teeth. External maxillipeds surpassing anteriorly the pterygostomial groove, reaching the same level of suborbital teeth. Afferent branchial openings largely oval, obliquely directed, borders almost reaching the lateral borders of carapace; base of the epipods of the third maxillipeds visible in normal position through the setose openings. Abdomen almost reaching anteriorly the first thoracic sternite. Sternum almost glabrous. Thoracic sternites and coxae smooth.

Antennule (Fig. 11A): Peduncle 3-segmented, basal segment globose. Outer flagellum 6-segmented, with numerous aesthetascs on segments 2-5; distal segment with 2 short subterminal setae and 2 long terminal setae, the apicalmost one longer than the entire outer flagellum. Inner flagellum 3-segmented, with no setae on the proximal segment, 4 setae on the second, and 8 or 9 setae on the distal segment. Antenna (Fig. 11B, b): Profusely tomentose, especially on the peduncle, gradually less tomentose toward apical segments; distal peduncular segment invested with 6-8 long setae; basal peduncular segment almost devoid of setae; flagellum composed of 19 segments, some of them invested with long setae, others with short setae. Mandibles (Fig. 11G): Very similar to those of the megalopa, but the 3-segmented palp now with 1,0,14 setae on its first to third segments. Maxillule (Fig. 11D, d): Endopod consisting of 2 segments, each with 2 setae; distal segment strongly flected; basal endite invested with 35 setae-spines; coxal endite curved, armed with 17 setae. Maxilla (Fig. 11E, e): Endopod slender distally, with 3 proximal and 3 distal setae; basal endite bilobed, with 19-21 setae, one of which is minute and placed basally; coxal endite almost vestigial, with 2 short setae; scaphognathite with numerous marginal setae and minute setae on surface. First maxilliped (Fig. 12A): $3 / 4$ of the endopod surface tomentose; entire borders fringed with short setae; basal endite broad, profusely setose; coxal endite smaller, tomentose and also highly setose; exopod with 4 medial and 5 outer-distal setae on its distal segment marginally, and 12 plumose setae on the distal segment. Epipod with broadly triangular base, invested with 5 proximal plumose setae and 26-27 long naked setae. Second maxilliped (Fig. 12B): Endopod 5-segmented, with 2 setae on the proximal segment and 8, 4, 14, 10 setae on the subsequent segments; distal 2 segments invested with rigid setae and strong spines. Exopod 2-segmented, with 7 marginal setae and 3-4 outer-apical plumose setae on elongate basal segment; distal segment with 10-11 long plumose 
setae. Epipod with 7-8 naked setae; podobranch more developed than in the megalopa stage. Protopod tomentose in basal portion, invested with 19-21 plumose setae. Third maxilliped (Fig. 12C): Surface (except the epipod) highly tomentose, and evidently more setose than in the previous stage, each segment generally as in

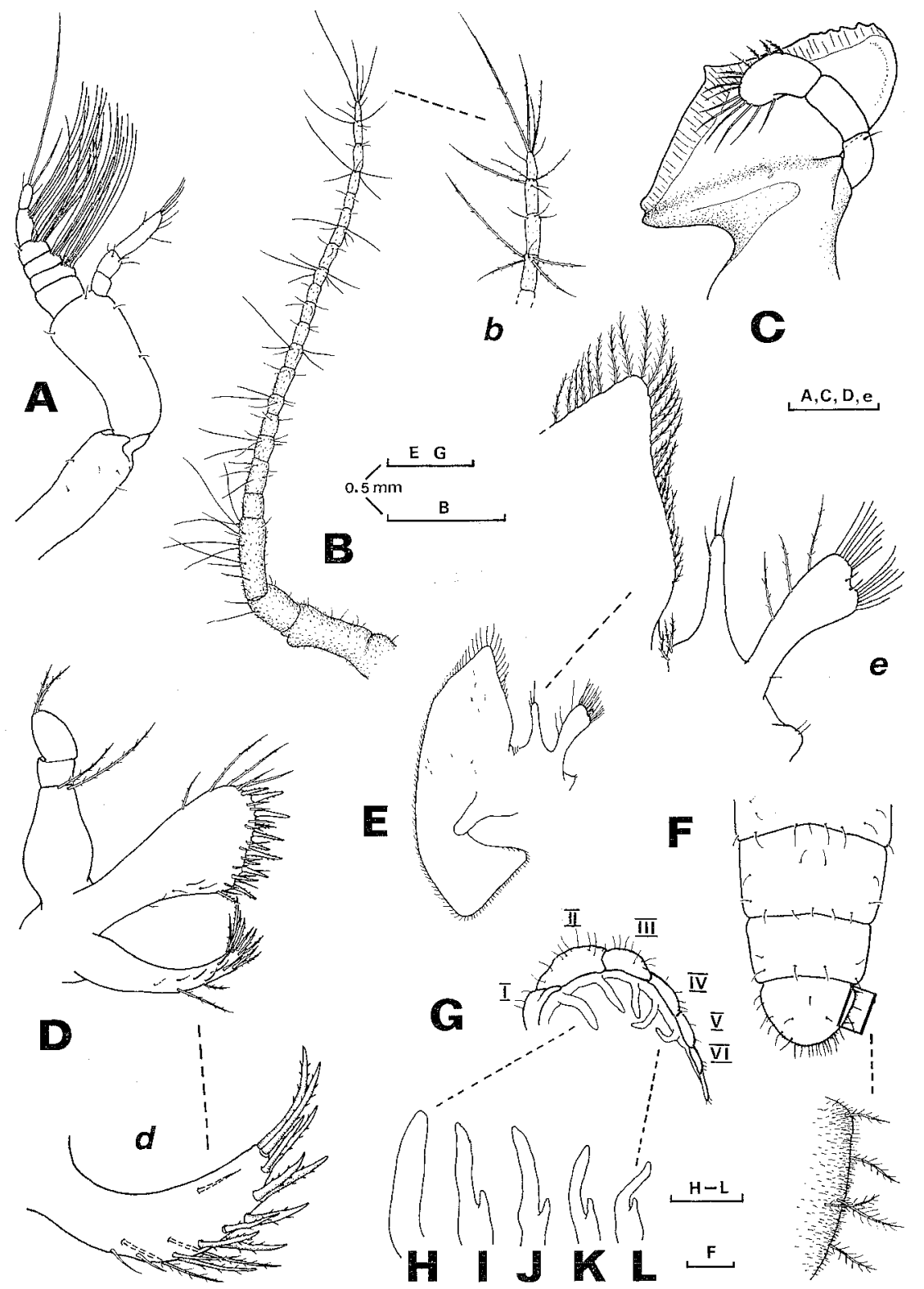

Fig. 11. Nobilum japonicum japonicum, first crab. A, antennule (basal segment omitted); B, antenna; b, distal portion; $\mathrm{C}$, mandible; $\mathrm{D}$, maxillule, complete; $\mathrm{d}$, coxal endite, from another specimen; $\mathrm{E}$, maxilla, complete; e, detail of inner endites; $\mathrm{F}$, abdomen, dorsal view; $G$, abdomen, lateral view; H-L, first to fifth pleopods. Scale bars $=0.2$ $\mathrm{mm}$, except when indicated for $0.5 \mathrm{~mm}$. 
the megalopa, but merus broader; base of epipod profusely setose, its elongated portion with 50-53 long naked setae.

Pereiopods (Figs 8C, 12D-G, 24C, F): Chelipeds shorter than carapace, similar, profusely tomentose, with long setae on upper surface of merus, carpus, palm and

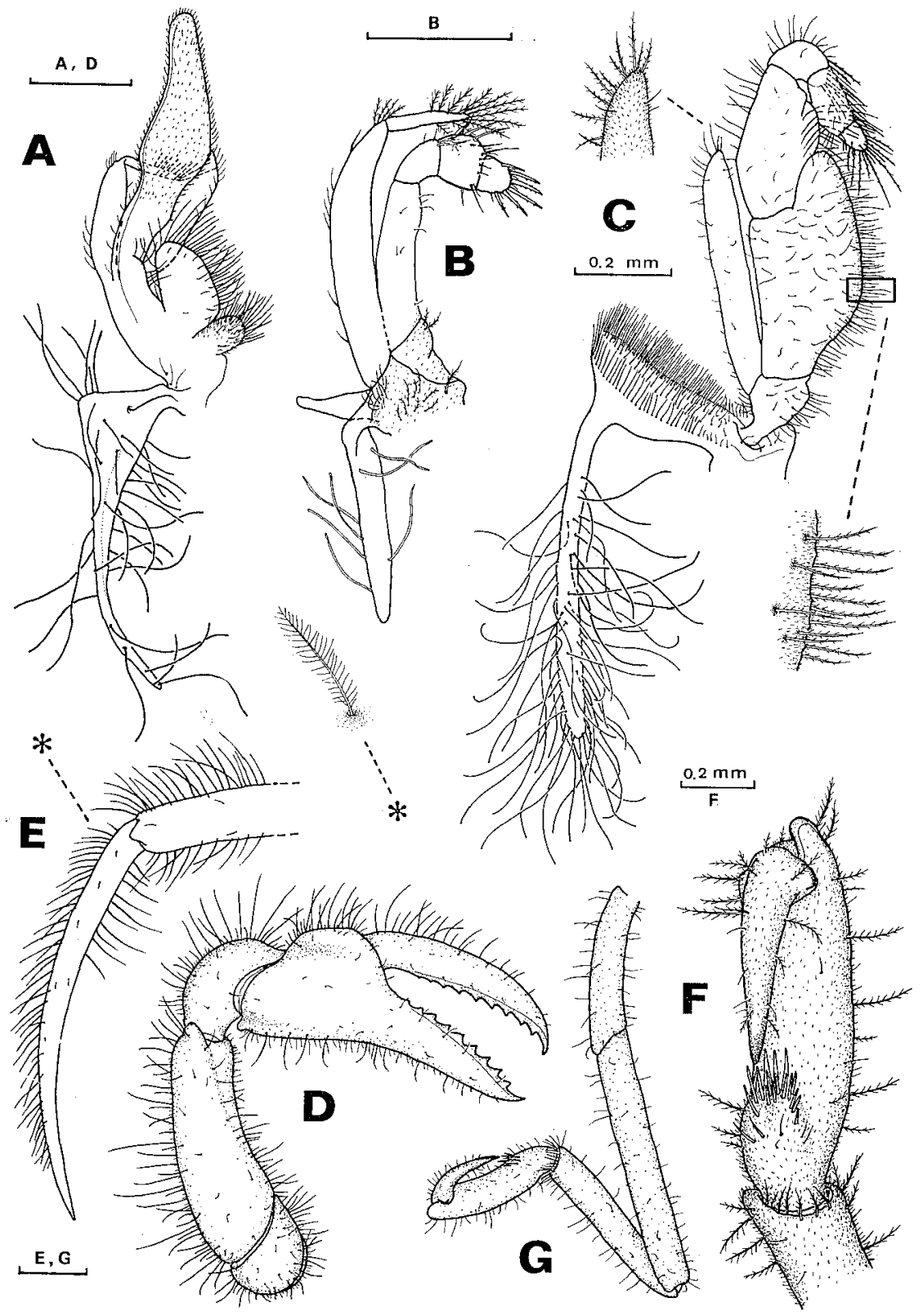

Fig. 12. Nobilum japonictm japonicum, first crab. A-C, first to third maxillipeds (in C, details of inner setation of ischium and of distal portion of exopod); D, cheliped; E-G, third to fifth pereiopods (asterisk indicates a detail of dactyl setae in $\mathrm{E}$ ). Scale bars $=0.5$ $\mathrm{mm}$, except for $\mathrm{G}$ and $\mathrm{F}$. 
movable finger; fingers armed with strong pointed teeth; tips also pointed. Pereiopods 2-3 very similar, highly tomentose, except on distal half of dactyli, as long as 3 times (2nd pereiopod) or 3.5 times ( $3 \mathrm{rd}$ pereiopod) the carapace length; upper and lower borders of propodus fringed with long setae, longer than those of proximal segments; dactyli fringed with long setae on almost the entire upper (=outer) border, but only on the proximal one-third of the inner border, flattened, elongate, slightly longer than propodus, and 2 times longer than carpus. Pereiopods 4-5 reduced, subdorsal in position, often flected; propodus and dactylus very short, forming a subchela; inner proximal protuberance of propodus strongly setose and spinous, rigid setae and spines also on distal border of carpus; tomentum evenly covering all segments; dactylus conical, shorter than propodus, and shorter than one-half the carpus length.

Abdomen (Fig. 11F, G): Dorsoventrally flattened; 6 segments and telson all highly tomentose, and invested dorsally with setae. Pleopods (see Fig. 11G-L) on segments $1-5$, the first pair uniramous and digitiform; pleopods $2-5$ biramous, each with long exopod, 6 times the length of the short endopod. Telson: Longer than broad, with margins almost perfectly circular, fringed with more setae on borders than dorsally.

\section{2-3. Remarks.}

Names previously used in Japan: Dorippe japonica Von Siebold, 1824; Neodorippe (Neodorippe) japonica (Von Siebold, 1824).

Japanese name: Heike-gani.

The megalopa of this species lasted 9-11 days in the laboratory before moulting to the first crab stage. Both postlarval stages virtually did not swim, and carried fragments of shells or rocks dorsally by using the fourth and fifth pereiopods.

\section{Paradorippe granulata (De Haan, 1841)}

3-1. Last (fourth) Zoea (Figs 13-15, 22).

Measurements: Rostral spine length $8.57 \mathrm{~mm}$; dorsal spine length $10.86 \mathrm{~mm}$; distance between tip of rostral and tip of dorsal spine $24.7 \mathrm{~mm}$.

Carapace (Figs 13A, 15A): Rostral and dorsal (= posterior) spines very long, apparently smooth, the former 3.3 times, the latter 4.2 times longer than cephalothorax; carapace hard, oval in dorsal view; lateral spines absent; ventrolateral borders of carapace fringed with 16 setae.

Antennule (Fig. 13C): Broad basally, with 2 proximal setae, segmentation indistinct; endopod as long as the indistinct basal segment of outer flagellum, unsegmented, unarmed; outer flagellum indistinctly 3-segmented, with 1,8,5 aesthetascs (in the distal group, the shortest aesthetasc fine, plus an additional short seta). $A n$ tenna (Fig. 13D): Spinous process slightly longer than exopod, with minute spinules on either side of distal half; exopod with 2 distinct setae at its distal one-third; endopod unsegmented, longer than one-half of spinous process. Mandibles (Fig. 13D): 


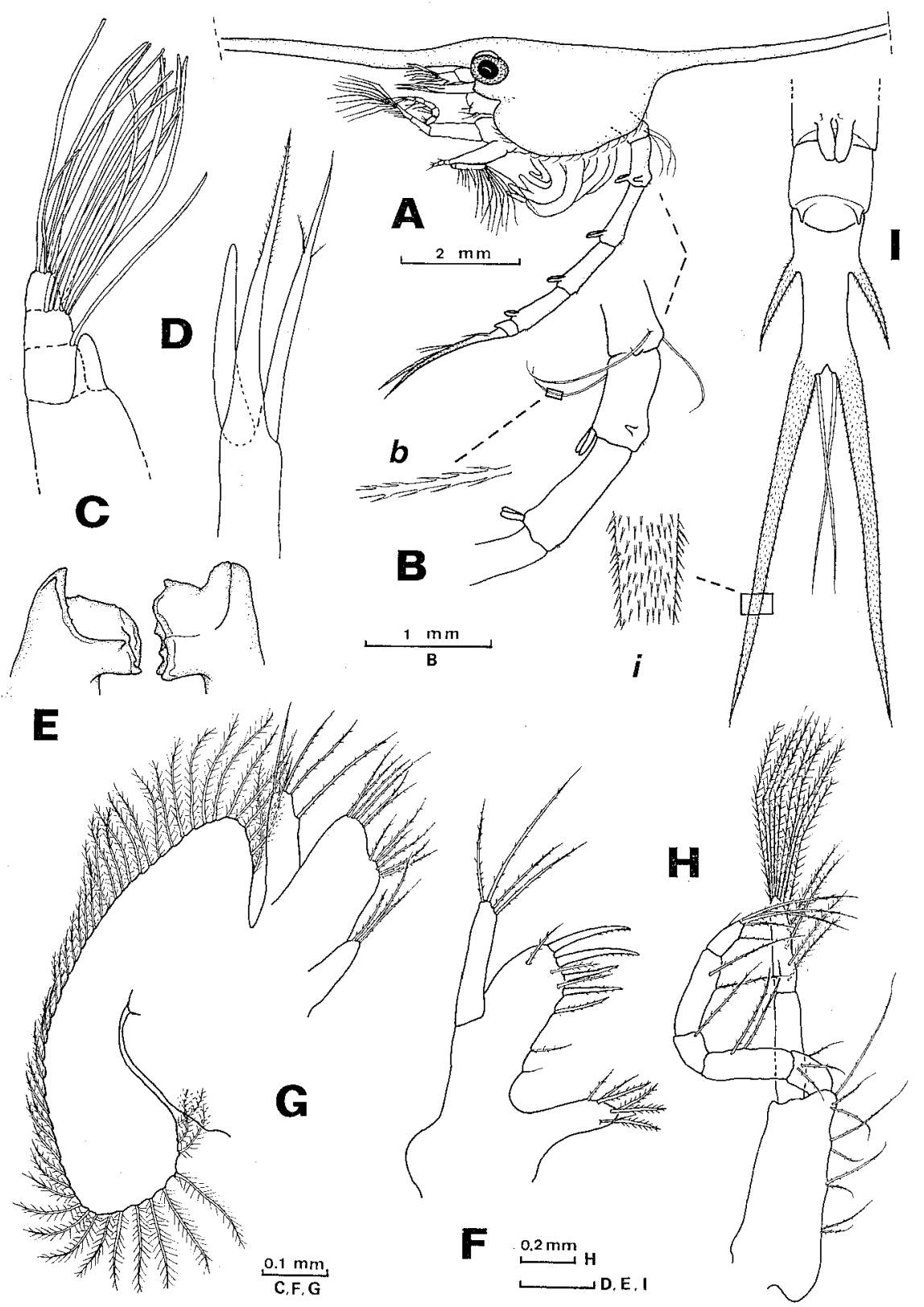

Fig. 13. Paradorippe granulata, fourth zoea. A, zoea, complete (rostral and dorsal spines partially illustrated), lateral view; $B$, abdomen (partially), lateral view; $b$, detail of seta of the first segment; $\mathrm{C}$, antennule (basal portion omitted); D, antenna; E, both mandibles; F, maxillule; $G$, maxilla; $H$, first maxilliped; I, distal segments of the abdomen and telson; $i$, detail of spinulation of furca, as observed by light microscope (compare with Fig. 22 F). Scale bars, as indicated. 


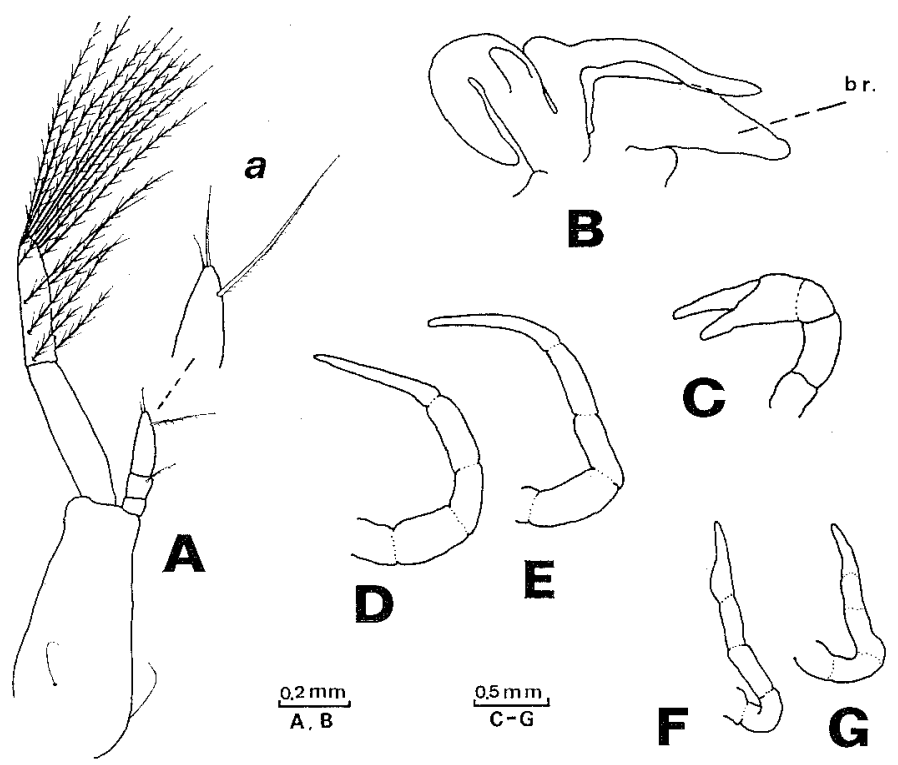

Fig. 14. Paradorippe granulata, fourth zoea. A, second maxilliped; a, detail of apical setation of endopod; B, third maxilliped; G-G, first to fifth pereiopods; br., branchia. Scale bars, as indicated.

Both somewhat different in dentition; incisor and molar processes well-developed, toothed. Maxillule (Fig. 13F): Endopod apparently unisegmented, with 4 terminal setae; basal endite with 10 setae-spines; coxal endite with 7 setae. Maxilla (Fig. 13G): Endopod with 3 terminal and 1 subterminal setae; basal endite bilobed, each lobe with 6 setae; coxal endite short, slender, with 3 distal setae; scaphognathite with 51 marginal setae. First maxilliped (Fig. 13H): Basis with 9 marginal setae, arranged 2,2,2,3; endopod longer than exopod, often curved, 5-segmented, with 3 setae on the proximal segment and $2,1,2,4+2$ setae on the subsequent segments; exopod with 14 long plumose setae, of which two pairs are subterminal. Second maxilliped (Fig. 14A, a): Basis with only 2 setae, proximal in position; endopod shorter than basal segment of exopod, 3-segmented, with no setae on the proximal segment, 1 on the second, and $2+1$ setae on the distal segment; exopod invested with 16 long plumose setae, arranged into pairs along the entire length of the distal segment. Third maxilliped and pereiopods (Fig. 14B, G-G): Rudimentary, indistinctly segmented, non functional, visible laterally; chelipeds incipiently chelate, pereiopods $2-5$ pointed distally.

Abdomen (Fig. 13A, B): Subcylindrical, slender, consisting of 6 segments plus the telson; first somite with 3 long dorsal setae, the mid-dorsal seta short, the other ones reaching beyond the posterior margin of second somite; this somite with a prominent dorsoposterior elevation and 2 posterolateral knobs; somites $2-5$ each with 2 minute setae mid-dorsally and a pair of rudimentary pleopods mid-ventrally; sixth segment short, with 2 short ventrolateral projections, which are not pleopods. Telson 
(Fig. 13I): Elongate, slightly longer than abdominal segments $4+5$, armed laterally with 2 prominent spines, placed on the proximal one-third, finely spinulose. Furcae very long, highly spinulose, somewhat divergent posteriorly, so that the distance at tips is about 1.2 times the distance between the tips of lateral spines of the telson; 2 long inner setae emerging from close to the median cleft, reaching about $2 / 3$ the length of the furcae. Smooth portion in the telson comprises its entire stem, excepting the lateral spines.

\section{3-2. Megalopa (Figs 15-17, 23).}

Measurements: Carapace length $2.93 \mathrm{~mm}$; maximum carapace width $3.10 \mathrm{~mm}$.

Carapace (Fig. 15C, D): Broader than long, regions incipiently demarcated, almost flattened dorsally, sparsely setose, and finely spinulate. Front broad, projected anteriorly, depressed medially, margin bilobed, open M-shaped, finely crenulate and granulate. Orbital fissure distinct, open. Outer-orbital teeth pointed distally, spinulate on borders, evidently not reaching laterally the hepatic border; inner orbital margin notched medially. Eyes short, somewhat oblique, not extending beyond the outer-orbital teeth. Outer hepatic regions moderately expanded laterally; branchial regions broadly expanded. Abdomen partially hidden beneath the carapace, so that together with coxae of pereiopods $2-5$ are visible in dorsal view. Coxae broadened basally, spinulate, sparsely setose. Endostome visible in dorsal view, surpassing the frontal lobes.

Antennule (Fig. 16A, a): Peduncle 3-segmented: basal segment globose, setose proximally; median and distal segments similar in length. Outer flagellum 4-segmented: proximal segment devoid of aesthetascs; segments 2-4 each invested with numerous aesthetascs, of which the distal group is medial in position; distal segment with 2 long apical, unequal setae, the longer one surpassing the length of outer flagellum. Inner flagellum 2-segmented, distal segment with 6 terminal and 3 subterminal setae. Antenna (Fig. 16B, b): Peduncle 3-segmented, tomentose; basal segment spinose laterally, with 2 apical protuberances; distal segment invested with long setae. Flagellum composed of 10 short segments, the basal one unarmed, the remaining with short setae, most of them shorter or equal to length of respective segment; apical segment with 5-6 setae, the longest one as long as the length of segments 7-10. Mandibles (Fig. 16C, $\mathrm{C}_{1}$ ): Asymmetrical, slightly different in morphology of cutting edge. Mandibular plate hardened, spade-shaped, broadly triangular, with 6-7 minute teeth and 2-3 blunt projections on inner borders of cutting edge. Palp 3-segmented, with 11 setae on the distal segment. Maxillule (Fig. 16 D): Endopod 2-segmented, distal one strongly flected, each segment with 2 apical setae; basal endite with 29 setae-spines, of which 4 setae are proximal in position; coxal endite curved, with 15 setae. Maxilla (Fig. 16E): Endopod with 3 outerproximal and 2 distal setae; basal endite bilobed, narrower proximally, with 8-9 setae on proximal lobe and 12-13 on distal lobe; coxal endite reduced, urilobed, invested with 2 short terminal setae; scaphognathite broadly expanded, fringed with 137-140 setae (in another specimen, a total of 150-154 setae were observed). First 
maxilliped (Fig. 17A): Endopod greatly developed, with many setae along margins, distal border rounded, inner distal margin almost straight, outer distal surface invested with 5 long setae; basal endite oval, coxal endite small, each profusely setose on margins; exopod 2-segmented, proximal segment with 5-6 short setae, distal

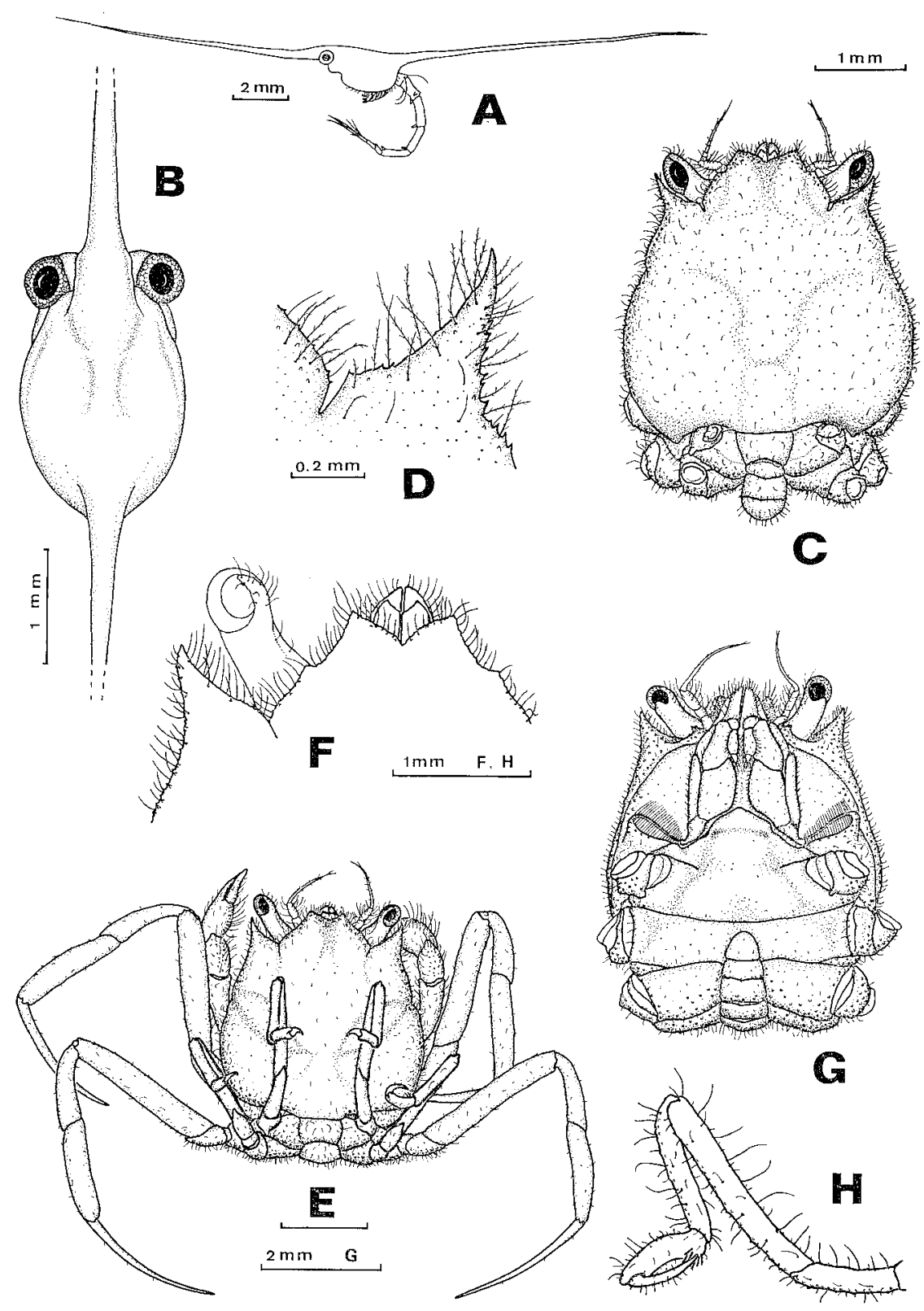

Fig. 15. Paradorippe granulata, fourth zoea (A, B), megalopa (G, D, H) and first crab (E-G). $A$, zoea, lateral view; $B$, zoea, dorsal view; $C$, megalopa, dorsal view; D, anterolateral angle of carapace; $\mathrm{E}$, first crab, complete, dorsal view; F, frontal region; $\mathrm{G}$, ventral view; $H$, fifth pereiopod of the megalopa. Scale bars, as indicated. 
segment with 11 long plumose setae. Epipod unarmed. Second maxilliped (Fig. 17B): Endopod 5-segmented, distal segment with rigid setae and spines; exopod 2-segmented, proximal segment long, with 2-3 marginal setae, distal segment with 12-13

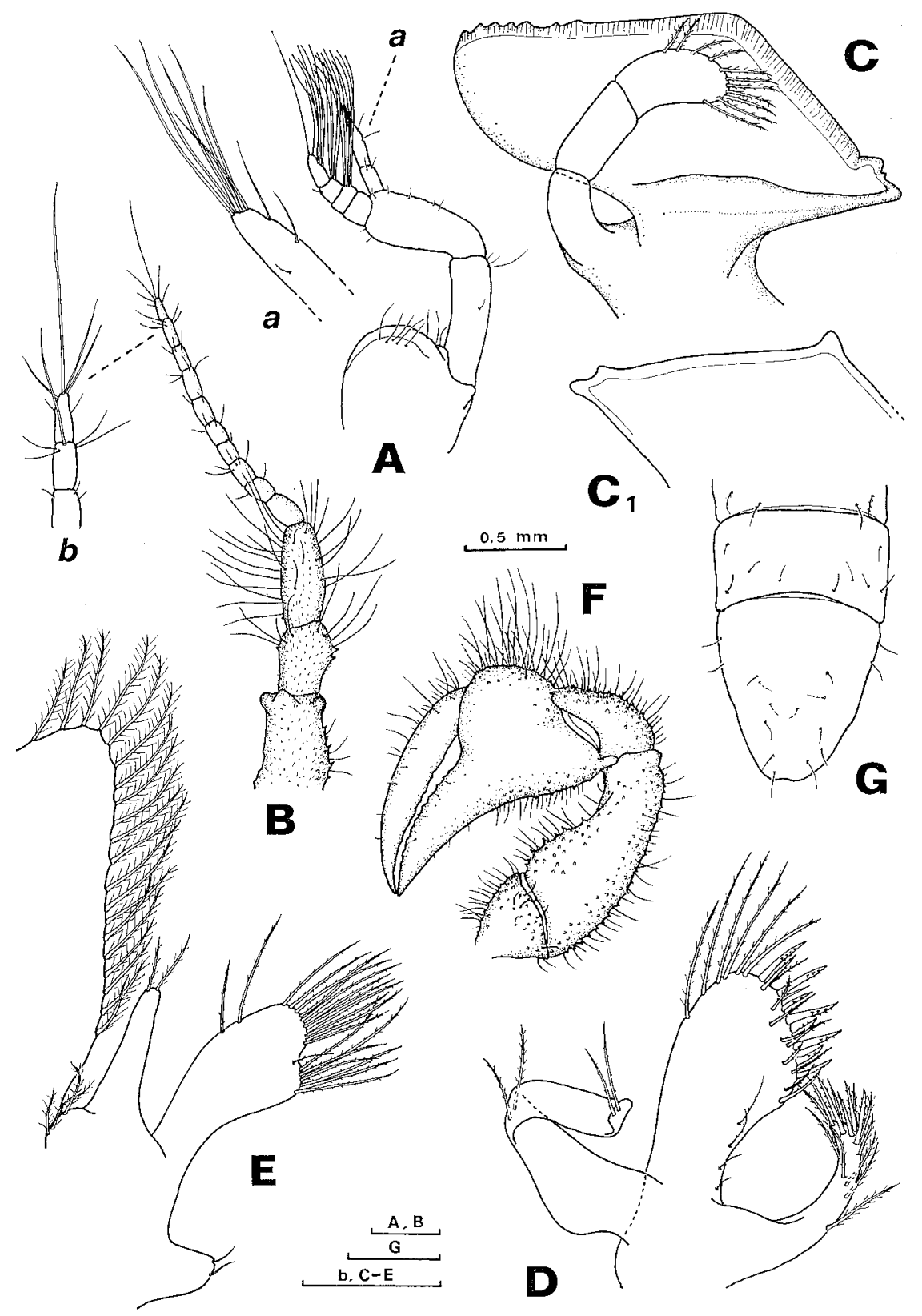

Fig. 16. Paradorippe granulata, megalopa. A, antennule; a, detail of inner flagellum; B, antenna; $b$, distal segments; $C, C_{1}$, mandibles; $D$, maxillule; $E$, maxilla, scaphognathite partially drawn; F, cheliped; $G$, distal segments of the abdomen, and telson, dorsal view. Scale bars $=0.2 \mathrm{~mm}$, except for $\mathrm{F}$. 
long plumose setae. Epipod reduced, unarmed; podobranch (=gill) rudimentary. Third maxilliped (Fig. 17C): Ischium and merus large, expanded, crenulate on margins, finely granulate and setose on surface; merus without stout projection on inner margin, carpus granulate and setose, distal 2 segments with numerous rigid

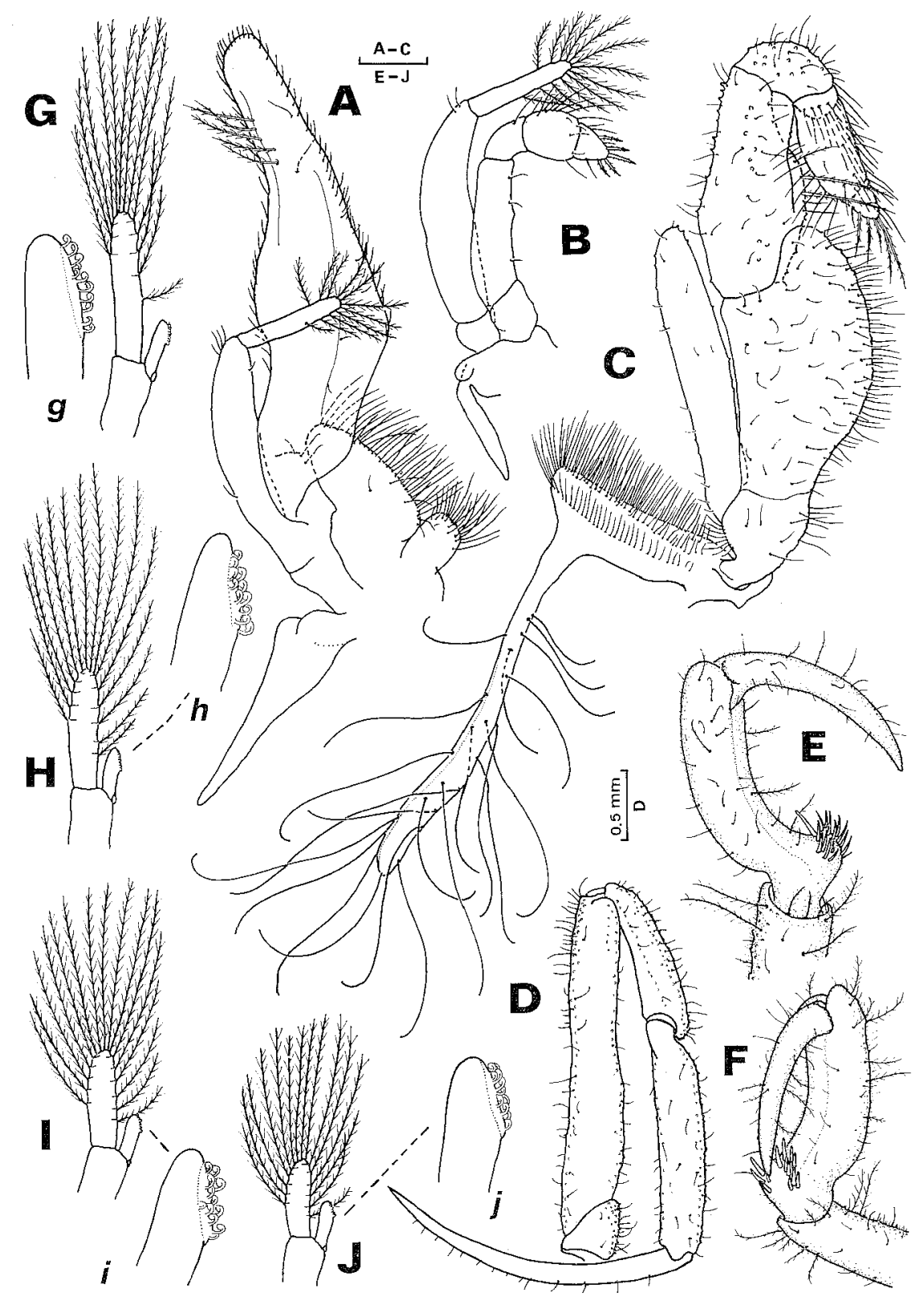

Fig. 17. Paradorippe granulata, megalopa. A-G, first to third maxillipeds; D, second perciopod; E, F, fourth and fifth pereiopods respectively, clistal segments; G-J, first to fourth pleopods; $\mathrm{g}-\mathrm{j}$, details of endopod of each pleopod. Scale bars $=0.2 \mathrm{~mm}$, except for $\mathrm{D}$. 
setae. Exopod unilobed, slender, somewhat crenulate along margins, more distinct on apical border. Epipod basally expanded, invested with 3-4 rows of numerous fine, rigid setae; slender portion invested with 21-22 long naked setae.

Pereiopods (Figs 15H, 16F, 17D-F, 23E-H): All well-developed, finely tomentose, setose, minutely granulate. Chelipeds short, similar, all segments (except the fingers) profusely spinulate, serrate along margins of the merus; palm spinulose on inner and outer borders, invested with long setae on outer (=upper) margin; fingers not distinctly toothed along inner margins, and clearly longer than the palm. Second and third pereiopods long, similar, third pereiopod slightly longer, minutely granulate on margins except the dactyli; dactylus flattened, longer than propodus, as long as merus. Pereiopods 4 and 5 evidently shorter than pereiopods $2-3$, subdorsal in position, subchelate, finely granulate along one margin; dactylus conical, strongly flected against the propodus, reaching to the proximal, setose propodal prominence; dactylus and propodus shorter than carpus.

Abdomen (Fig. 16G): Subcylindrical, consisting of 6 segments plus the telson, covered with fine tomentum and sparse setae. Sixth segment 2 times broader than long. Pleopods (Fig. 17G-J, g-j) well-developed, present on segments 2-5; no uropods. First pair of pleopods with 13 (right) or 15 (left) long plumose setae on exopod, and 12-13 small hooked setae on inner distal margin of the endopod; second pleopod with 15 long setae on exopod and 11 hooked setae on endopod, third pair with 14 (right) or 16 (left) plumose setae and 11-12 hooked setae, last pair with 15 (right) or 13 (left) plumose setae and 11-12 hooked setae. Telson (Fig. 16G): Elongate, 2.1 times longer than sixth abdominal segment, convergent distally; posterior margin rounded, with an incipient median sinus, invested with 2 proximal setae on either side and 7-8 setae dorsally; 3-4 setae on ventral surface.

\section{3-3. First Crab (Figs 15, 18, 19, 24).}

Measurements: Carapace length $4.54 \mathrm{~mm}$; maximum carapace width $4.64 \mathrm{~mm}$.

Carapace (Fig. 15E, F): General morphology similar to the megalopa. Carapace slightly broader than long, almost flattened dorsally, finely spinulate on borders, sparsely setose on surface. Front convergent anteriorly, somewhat depressed medially, bilobed, each lobe pointed, minutely crenulate. Endostome projecting anteriorly beneath the median frontal sinus, visible in dorsal view. Orbits open; tips of outerorbital teeth extending anteriorly to nearly the same level of frontal sinus, but not reaching laterally the hepatic margin. Two oblique, oval epibranchial areas are moderately demarcated. Abdomen not completely flected beneath the carapace, so that the coxae and proximal segments of pereiopods 4-5 are visible dorsally. Sternum (Fig. 15G): Endopod of first maxillipeds surpassing anteriorly the frontal margin; suborbital spines greatly reduced, granulate, reaching about one-fourth the length of outer-orbital teeth. External maxillipeds projected anteriorly beyond the suborbital spines. Afferent branchial openings oval, oblique, placed in front of the base of the third maxillipeds, finely granulate on borders. Anterolateral margins of carapace, coxae, thoracic sternites $3-5$ and abdomen minutely granulate, sparsely setose. 
Antennule (Fig. 18A): Basal segment of peduncle globose, finely tomentose, invested with a group of 19-21 proximal setae. Outer flagellum 6-segmented, with tufts of $0,9,9,8,5,1$ aesthetascs; distal segment bearing an additional short, subterminal

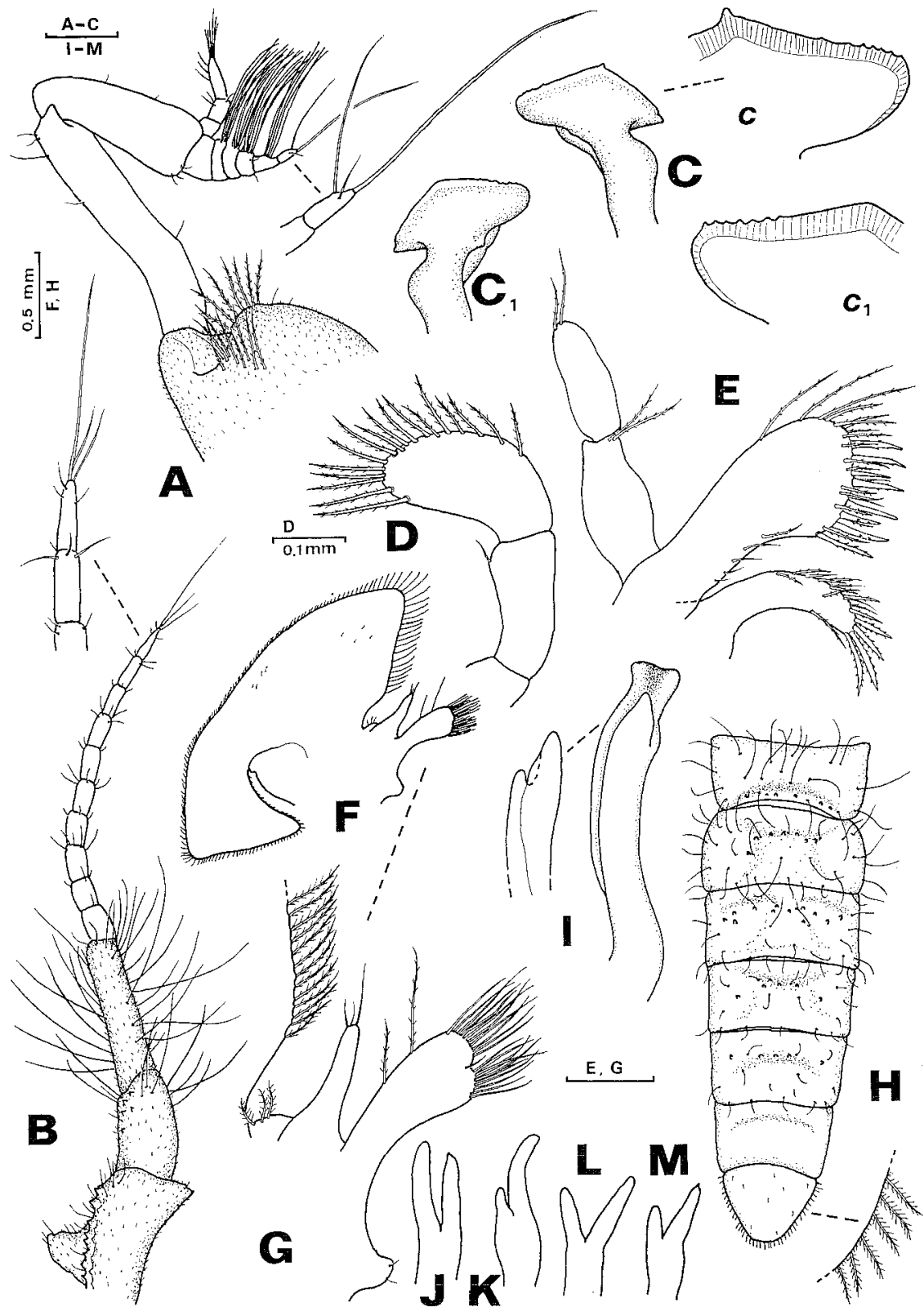

Fig. 18. Paradorippe granulata, first crab. A, antennule, with a detail of distal segment of outer flagellum; $\mathrm{B}$, antenna, with a detail of apical segments; $\mathrm{C}, \mathrm{C}_{1}$, mandibles, outer view; $c$, $c_{1}$, inner view; D, mandibular palp; E, maxillule; F, maxilla, complete; $G$, detail of inner endites; $\mathrm{H}$, abdomen, complete, dorsal view; I-M, first to fifth pleopods; I, inner and lateral views. Scale bars $=0.2 \mathrm{~mm}$, except for $\mathrm{D}, \mathrm{F}, \mathrm{H}$. 
seta and an extremely long apical seta, longer than the entire outer flagellum. Inner flagellum 3-segmented, with 0,3,6+3 setae. Antenna (Fig. 18B): Peduncle 3segmented, finely tomentose; basal segment with a proximal projection, inner border serrate, invested with short setae; distal segment (longest) with numerous long setae;

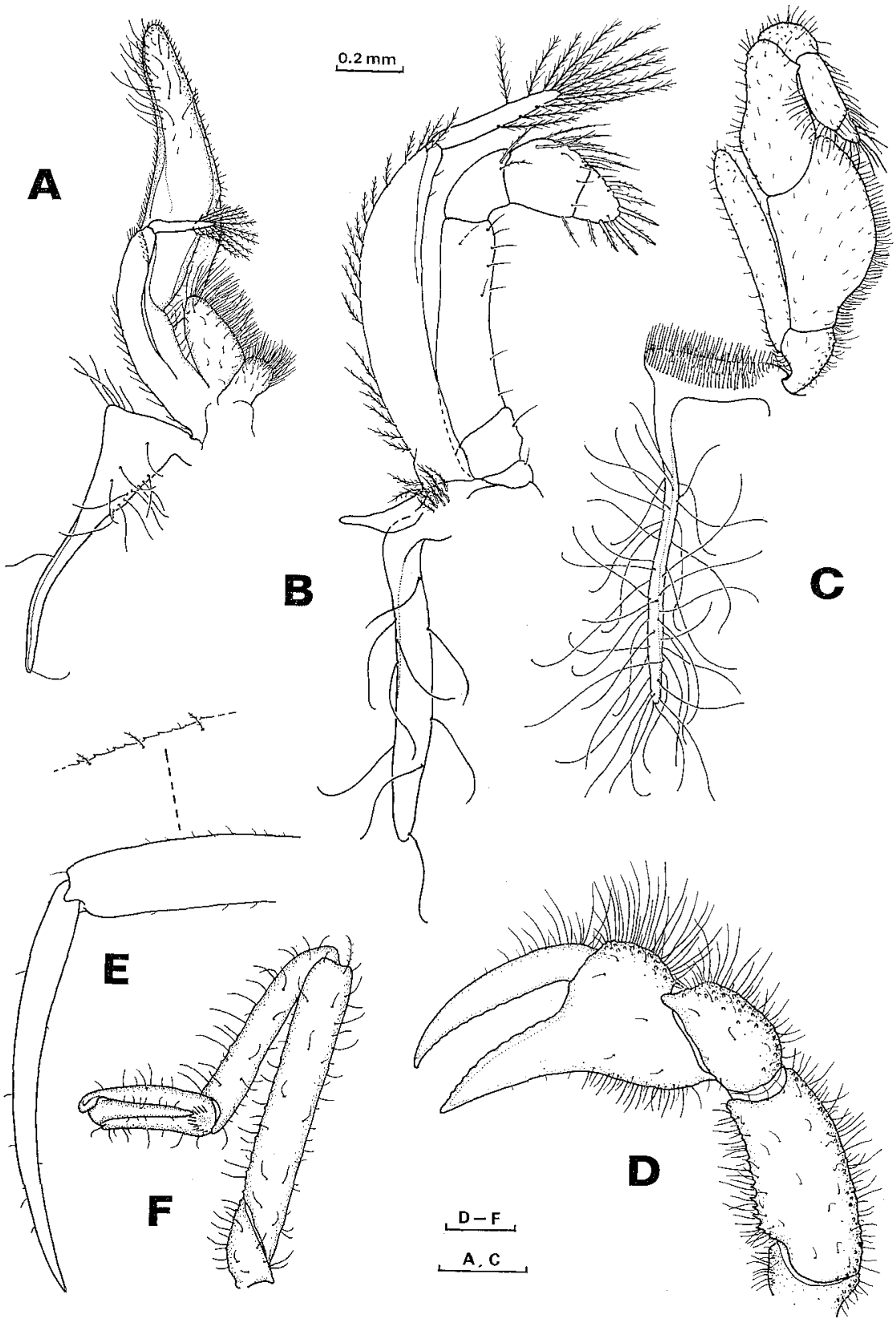

Fig. 19. Paradorippe granulata, first crab. A-C, first to third maxillipeds; D, cheliped; E, third pereiopod, with a detail of outer margin of propodus; $F$, fourth pereiopod. Scale bars $=0.5 \mathrm{~mm}$, except for $B$. 
median segment with setae distally. Flagellum composed of 10 segments, most except the basal, with short setae, mostly as long as $1 / 3-1 / 2$ of the length of their respective segment; distal segment with 5 short setae and 1 long seta, the latter as long as the length of segments 7-10 together. Mandible (Fig. 18C, $\mathrm{C}_{1}, \mathrm{c}, \mathrm{C}_{1}, \mathrm{D}$ ): Morphology of mandibular plate as in the megalopa; palp 3-segmented, with no setae on the proximal segment, 1 on the second, and 16-17 setae on the distal segment. Maxillule (Fig. 18E): Endopod 2-segmented, distal segment normally greatly flected, each segment with 2 distal setae; basal endite with 30-32 setae-spines, of which 5 fine setae are proximal; coxal endite curved, invested with 16-17 setae. Maxilla (Fig. 18F, G): Endopod slender, with 3 outer proximal, and 2-3 apical setae; basal endite indistinctly bilobed, with 9 fine setae on proximal lobe, 1 short seta medially, and 13 on distal lobe (total 23); coxal endite as a bud, invested with 2 minute setae. Scaphognathite fringed with 225-227 setae. First maxilliped (Fig. 19 A): Free portion of the endopod (about distal half) hardened, fringed with short setae, granules and numerous long setae on distal surface; basal and coxal endites profusely setose on inner margins and surface; basal segment of the 2-segmented exopod fringed with 12-13 setae on proximal half and 5 outer-distal setae, distal segment with 12 long plumose setae. Epipod with broad triangular base, invested with 5 setae on outer apex and 13 naked setae more distally. Second maxilliped (Fig.
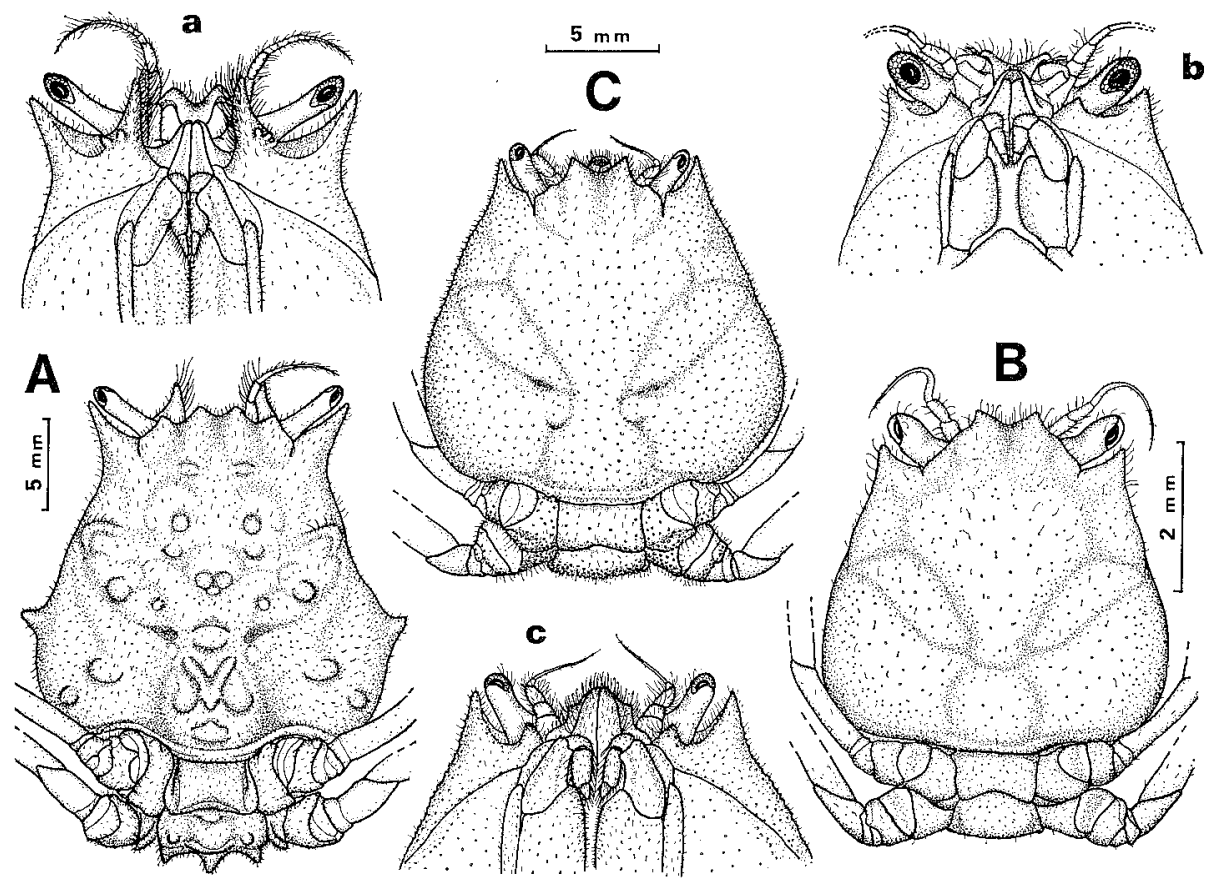

Fig. 20. Adults of dorippid crabs. A, Dorippe frascone, dorsal view (male, G. L. $19.3 \mathrm{~mm}$ ); B, Nobilum japonicum japonicum, dorsal view (male, C. L. $4.59 \mathrm{~mm}$ ); C, Paradorippe granulata, dorsal view (male, C. L. $14.7 \mathrm{~mm}$ ). a-c, anterior portion of carapace, ventral view (antennules omitted in a, c). Scale bars, as indicated for A, B, C. 
19B): Endopod 5-segmented, apical 2 segments with rigid setae and spines. Exopod 2-segmented; basal segment elongate, with 20-21 setae along outer margin and 2 short setae on distal inner portion; distal segment slender, with 12 long plumose setae. Epipod with 8-9 long naked setae. Podobranch reduced, with a group of
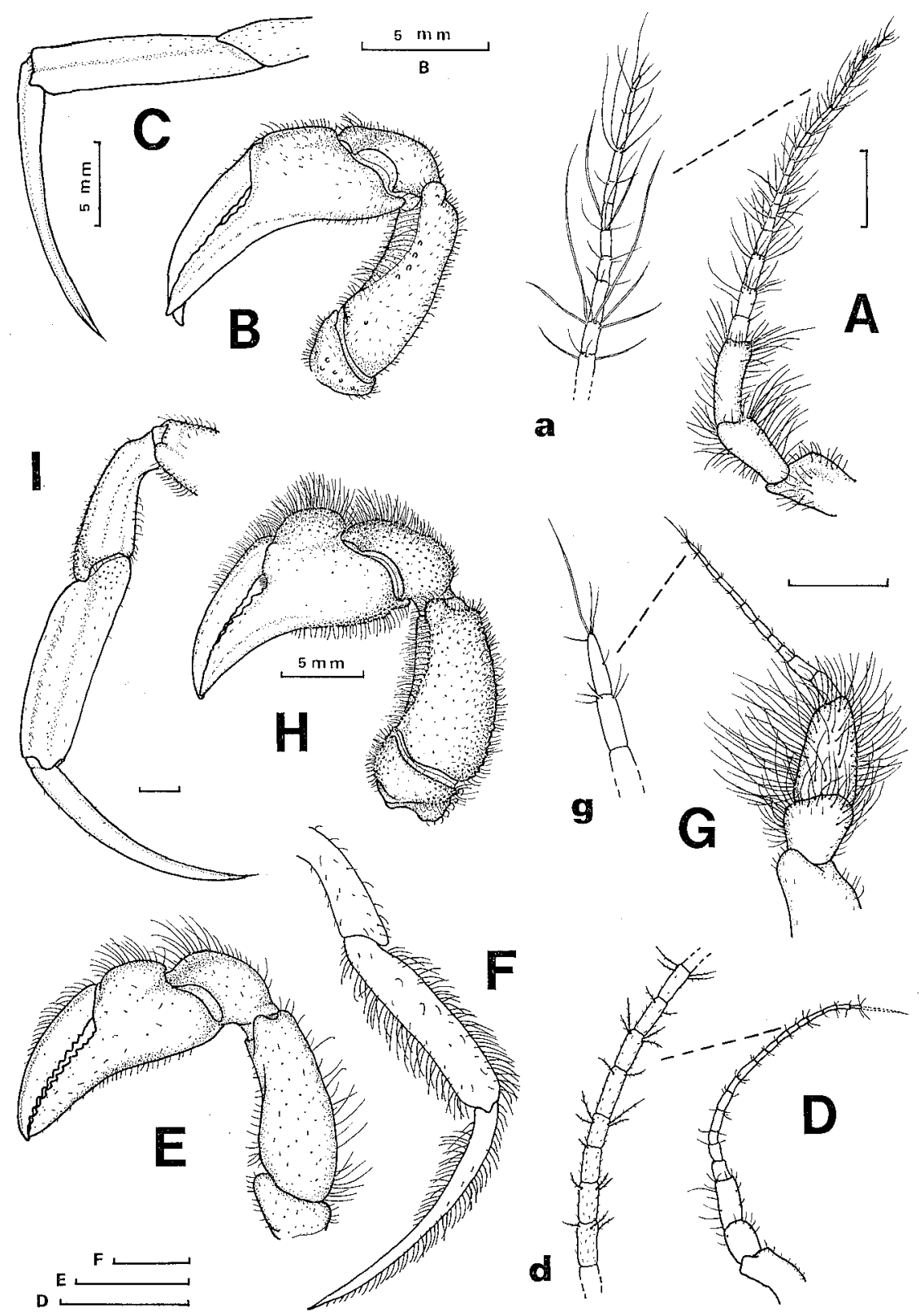

Fig. 21. Adults of dorippid crabs. A-C, Dorippe frascone (male, C. L. $19.3 \mathrm{~mm}$ ); D-F; Nobilum japonicum japonicum (male, G. L. $4.59 \mathrm{~mm}$ ); G-I, Paradorippe granulata (male, C. L. $14.7 \mathrm{~mm}$ ). A, D, G, antenna; B, E, H, cheliped (left); C, F, I, second pereiopod; a, d, g, details of antennal segments. Scale bars $=1 \mathrm{~mm}$, except for $\mathrm{B}, \mathrm{C}, \mathrm{H}$. 
9-10 setae near its base. Third maxilliped (Figs 19C, 24D, E): Evenly setose, finely granulate except on epipod, morphologically similar to that of the megalopa, but differing from the latter in the shape of merus, which is concave on outer margin. Epipod with 3-4 rows of numerous setae on basal portion, and 41-43 long naked setae on the slender distal portion.

Pereiopods (Figs 15E, 19D-F, 24B): Sparsely setose, finely granulate. Chelipeds shorter than carapace, granulate, serrate along inner margin of merus, invested with long setae on carpus, outer (=upper) margin of palm and proximal upper margin of movable finger; cutting edge of chelae with indistinct teeth; movable finger almost edentate; shorter setae on inner (=lower) margin of palm. Second and third pereiopods about 2.4 times as long as the carapace; third pereiopod slightly longer than the second one, both sparsely setose, minutely serrate at outer border of propodus; dactylus long, about 1.5 times the propodus and 2 times the carpus, flattened, slightly curved. Fourth and fifth pereiopods shorter, subdorsal in position, subchelate, often strongly flected, minutely granulate on borders; dactylus conical, often flected against the proximal, setose protuberance of propodus, slightly shorter than propodus, and markedly shorter, 1/2 of carpus; no rigid setae on distal margin of carpus.

Abdomen (Fig. 18H): Dorsoventrally flattened, with dorsal granules and setae, but progressively glabrous toward distal somites, sixth segment smooth. Pleopods (Fig. 18I-M) present on segments 1-5; first pleopod large, 2.5 times longer than the second, uniramous, truncate distally, with a longitudinal groove (apparently folded along mid-line), and a lateral, subterminal projection; second to fifth pleopods similar in size, with unarmed endopod and exopod. Telson (Fig. 18H): Basal width greater than its length, convergent distally, rounded marginally, covered dorsally with few setae, but fringed with numerous (38-40) setae along the entire margins; length of telson is now 1.3 times the sixth segment.

\section{3-4. Remarks.}

Name previously used in Japan: Dorippe granulata De Haan, 1841.

Japanese name: Samehada-heike-gani.

The megalopa of this species lasted 9-11 days in the laboratory before moulting to the first crab stage. No data could be obtained for the duration of the first crab stage. The megalopa and first crab stages were observed carrying dorsally over the carapace, fragments of shells or small rocks provided in the rearing vessels.

\section{Discussion}

Prior to a recent paper given by Quintana (1986) on leucosiid crabs, there have been no studies on early postlarval stages of crabs of the Section Oxystomata (see Felder et al., 1985), which accomodates the Dorippidae, Cyclodorippidae, Cymonomidae (sensu Manning \& Holthuis, 1981), Calappidae and Leucosiidae. Among these families, dorippids are peculiar in larval characters as suggested by Rice (1980a), who concluded that this section is not a natural group. The weakness in the 
affinities between dorippids and the other members of the Oxystomata can be better understood by comparing their larvae (for cymonomids see Wear and Batham, 1975; for calappids see Raja Bai, 1959; Fagetti, 1960; Hashmi, 1970; Hong, 1976; for leucosiids see Rice, 1980b; Salman, 1982, Quintana, 1986).
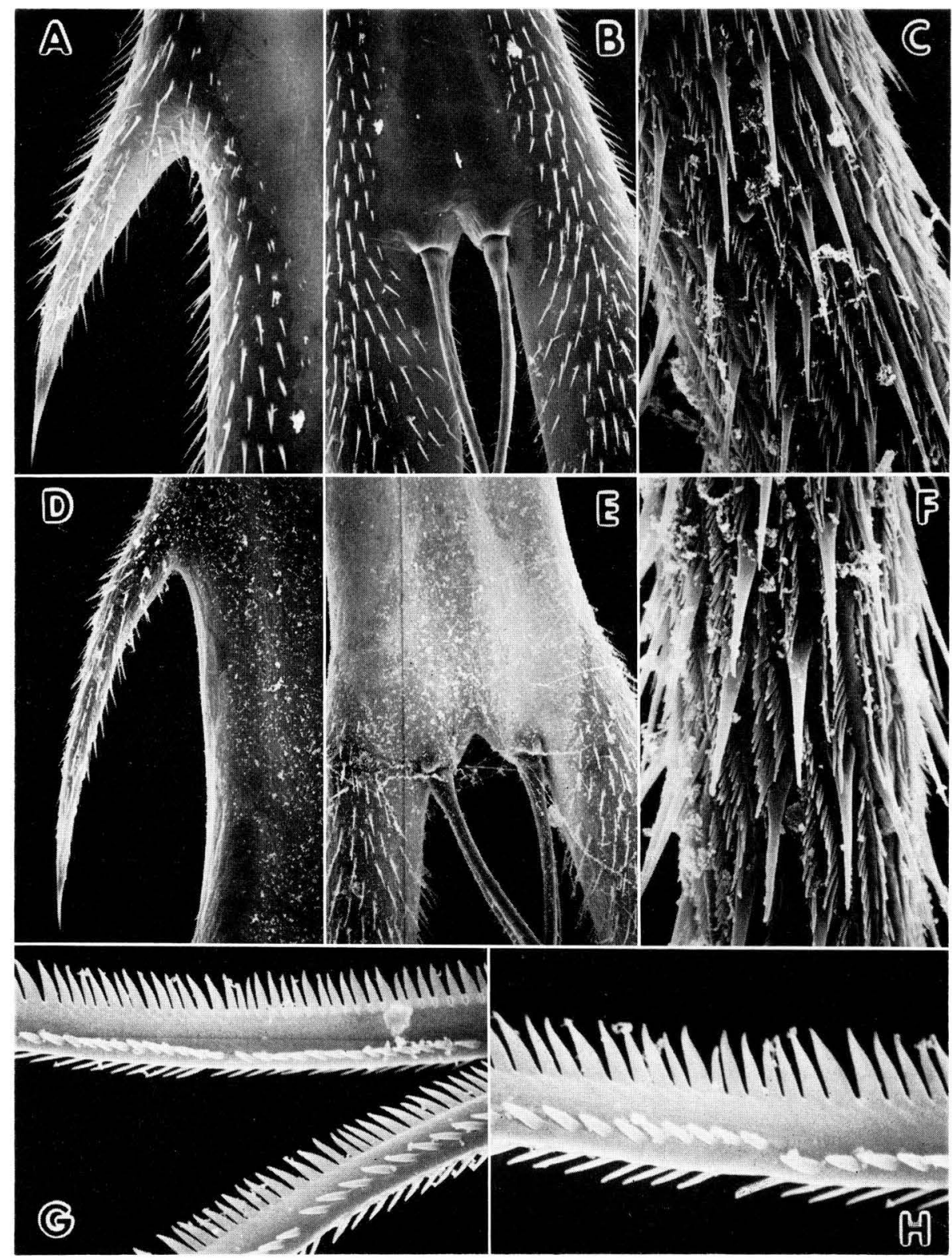

Fig. 22. Scanning electron micrographs of dorippids, fourth zoeal stage. A-C and G, Dorippe frascone; D-F and H, Paradorippe granulata. $\mathrm{A}(\times 500)$ and $\mathrm{D}(\times 350)$, lateral spine of the telson; B, E (both, $\times 350)$, mid portion of telson, ventral view; $\mathrm{C}(\times 1500)$ and $F(\times 2000)$, a portion of the telsonal furca (at distal one-third); $G(\times 2000)$ and $\mathrm{H}(\times 3500)$, details of the inner setae of the telson. 


\section{Dorippid zoeal stages.}

Among the few descriptions of developmental stages of Japanese dorippid crabs (subfamily Dorippinae, sensu Manning \& Holthuis, 1981) are the report of Aikawa (1937) on the first zoea of Paradoritpe granulata (as Dorippe granulata) and two zoeas that he attributed to the genus Dorippe, and the report of Kurata (1964) on zoea I to IV of the former species; both reports are based on planktonic material. The account of the complete larval development of Japanese dorippids reared in the laboratory seems to be only a report by Terada (1981), who described larvae of three dorippid species through the last zoeal stages, but he could not obtain early postlarval stages. His material included the species $D$. frascone (as $D$. dorsipes), $N$. j. japonicum (as Neodorippe japonica), and P. granulata (as Dorippe gramulata). Although Terada (op. cit.) obtained all the zoeal stages, some of the morphological changes, especially in the zoeal telson (p. 26: Fig. 3) prove to be rather abnormal, as the later stages exhibit a very short, aberrant telson, atypical of dorippids. At present, there are no reports in which the inner two setae of the telson are mentioned to become longer than the furcae, as he illustrated (see Aikawa, 1933, 1937; BourdillonCasanova, 1960; Kurata, 1964; Rice, 1980: 318). Among Terada's larvae, only the first zoea accords with those reported by several of the above mentioned authors in the shape and proportion of the telson furcae. The abnormalities in the later stages may be due to some deficiencies in Terada's rearing methods.

\section{Dorippid postlarval stages and their carrying behaviour.}

Most studies apparently have had difficulty in successfully obtaining early postlarval stages. Kurata (1964) noted that zoeas of Paradorippe granulata (the single dorippid inhabiting the waters off Hokkaido) were always abundant in the plankton, but the megalopas were never collected. Gilet (1952) described a late zoeal stage ("metazoea") and a megalopa, material he attributed to Dorippe lanata (now Medorippe lanata (L.), sensu Manning \& Holthuis, 1981). The late zoeas of the present study were collected from the plankton of Tosa Bay, southern Japan, and successfully moulted in the laboratory through the first crab stage. During the rearing, a curious behaviour was observed in all megalopas and also in the first crabs obtained. These postlarvae virtually did not swim, but carried fragments of shells or chips of rocks, provided in the glass vessels used in rearing. These materials were held dorsally over the body by the strongly curved propodus and dactylus of the last two pairs of pereiopods. The morphology of the fourth and fifth pereiopods clearly shows that the dactyli are not ambulatory (see Figs 3B, 8C, 15H and 23) but modified for this purpose. These observations at first made me consider the possibility that large zoeas had moulted to a first crab instead of to a megalopa, especially because of the great modification of the last two pairs of pereiopods and the absence of the long setae ("brachyuran feelers") on the inner margin of dactylus of the fifth pereiopod. But a detailed further observation, however, revealed that the appendages were clearly megalopal in characters (see Figs. 5, 9, 17).

The megalopas observed in the present three species, as a rule are large larvae 


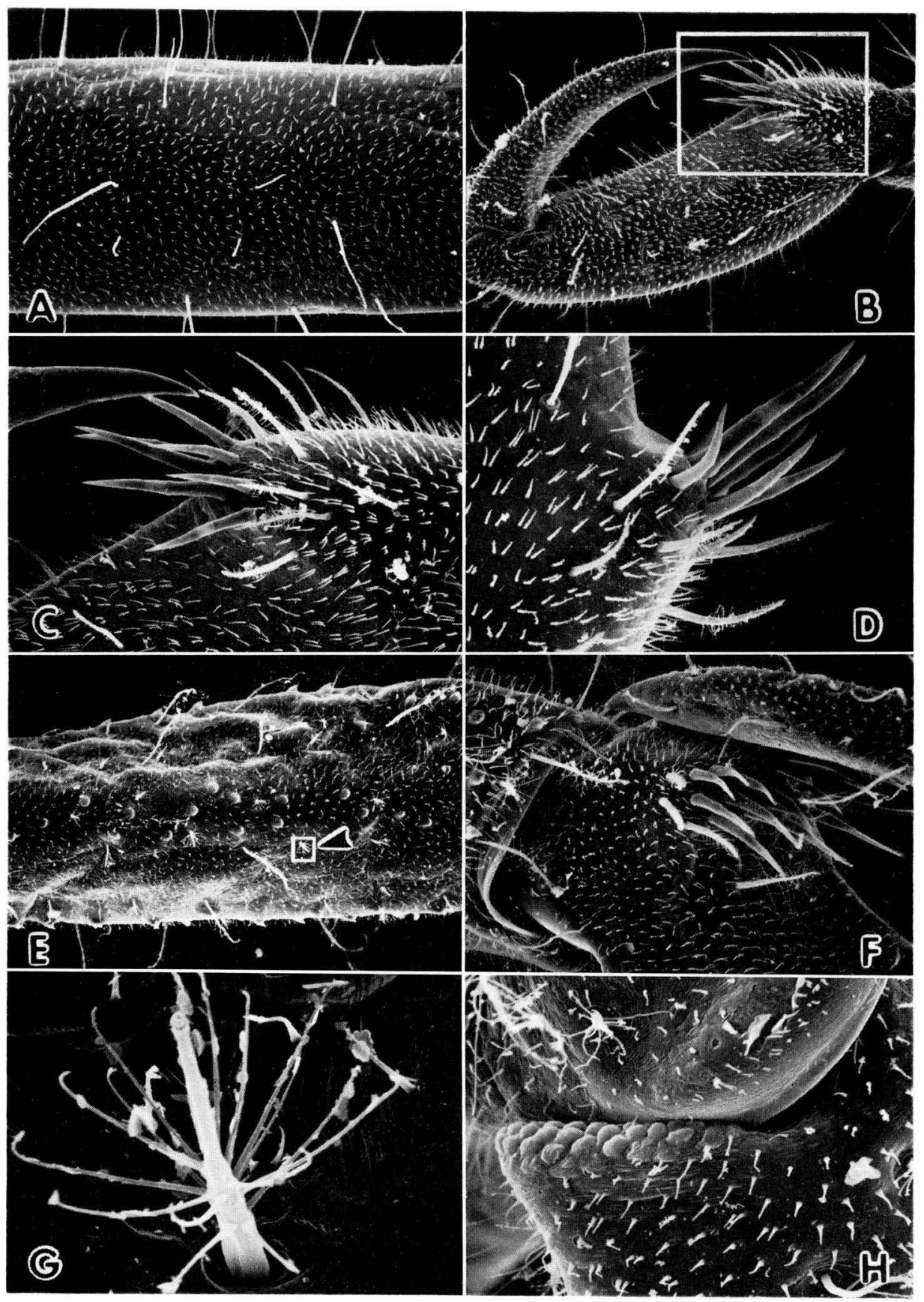

Fig. 23. Scanning electron micrographs of dorippids, megalopal stage. A-D, Dorippe frascone; A, second pereiopod, merus $(\times 200)$; B, fourth pereiopod, propodus and dactylus $(\times 150)$; C, detail of area indicated in $\mathrm{B}(\times 350)$; D, fifth pereiopod, propodal setae, $(\times 500)$; E-H, Paradorippe granulata. E, secend pereiopod, merus $(\times 200) ; \mathrm{F}$, fourth pereiopod, a portion of the carpus, propodus and dactylus $(\times 350)$; $\mathrm{G}$, detail of a seta indicated in $\mathrm{E}(\times 3500)$; $\mathrm{H}$, fifth pereiopod, detail of propodus and proximal portion (granulate) of the dactylus $(\times 1000)$. 
(C.L. about $2.9 \mathrm{~mm}$ ), which are rather benthic and weak swimmers. The behaviour of carrying small pieces of rocks dorsally, observed for the first time in the laboratory, presumably has been the reason why Kurata (1964) did not obtain planktonic megalopas. The difficulty in obtaining megalopas from the plankton may also be attributed to some diel migration so far not well known for dorippid megalopas, but this seems unlikely since during a 2-year study of night surface plankton (4-5 m depth) in Tosa Bay, no planktonic megalopas were collected (personal observations).

The carrying behaviour observed in the megalopa and first crab stages is evidence of their rather benthic habits, as it is in the adults; this behaviour has not been known previously in the megalopal stage, being apparently a particular case within the brachyuran crabs. The carrying behaviour in adults of dorippid species and allied groups has been reported in detail by Wicksten $(1982,1986)$ for a number of brachyuran crabs. Sakai (1976) also observed this behaviour in adults of dorippids from Japan. It is probable this behaviour is also exhibited by megalopas (and obviously first crabs) of other members of the family Dorippidae.

In general, the megalopal stage is often a modified transitional stage between the planktonic zoea and the benthic crab stages in almost all the brachyurans, and usually the megalopas differ morphologically from the first crab (Felder et al., 1985). However, the megalopal stage in the three dorippid species examined does not differ greatly in their morphology from that of the first crab, except in the structure of the pleopods. These abdominal appendages bear long plumose setae on the exopod and very short, hooked setae on the endopod. Certainly, the morphology of the modified fourth and fifth pereiopods, and the megalopal carrying behaviour seem to be precociously acquired in the ontogeny of the early postlarval stages. The last two pairs of pereiopods become distinctly subchelate in the megalopal stage, undergoing no previous transitional change; in the last zoea, the rudimentary pereiopods do not exhibit evidences of such a condition (see Fig. 14F, G).

The three species can be easily distinguished from each other at megalopal and first crab stages by the morphology of the carapace (both dorsally and ventrally), by the structure of the maxillule, maxilla, the epipods of the three maxillipeds, and by the setation of dactyli of the second and third ambulatory legs (other characters are listed in Tables 1 and 2). In the first crab stage, these characteristics become more apparent (cf. Figs 3, 8 and 15), and in the succeeding stages gradually become more similar to the adults (cf. Figs 20, 21).

\section{Adult characters.}

To supplement observations made on the early postlarval stages, additional adult specimens of the three species were examined, kindly provided by Dr. Konishi (D. frascone, 2 males; P. granulata, 3 males and 2 females) and Dr. Takeda $(N . j$. japonicum, 6 males). The diagnositc characters of the dactylus of the second and third pereiopods for the genus Nobilum, i. e., borders hairy (Fig. 21F), together with a rather smooth carapace, as pointed out by Manning \& Holthuis (1981, p. 30), and further figured by the same authors (1986) could be useful to recognize one of 


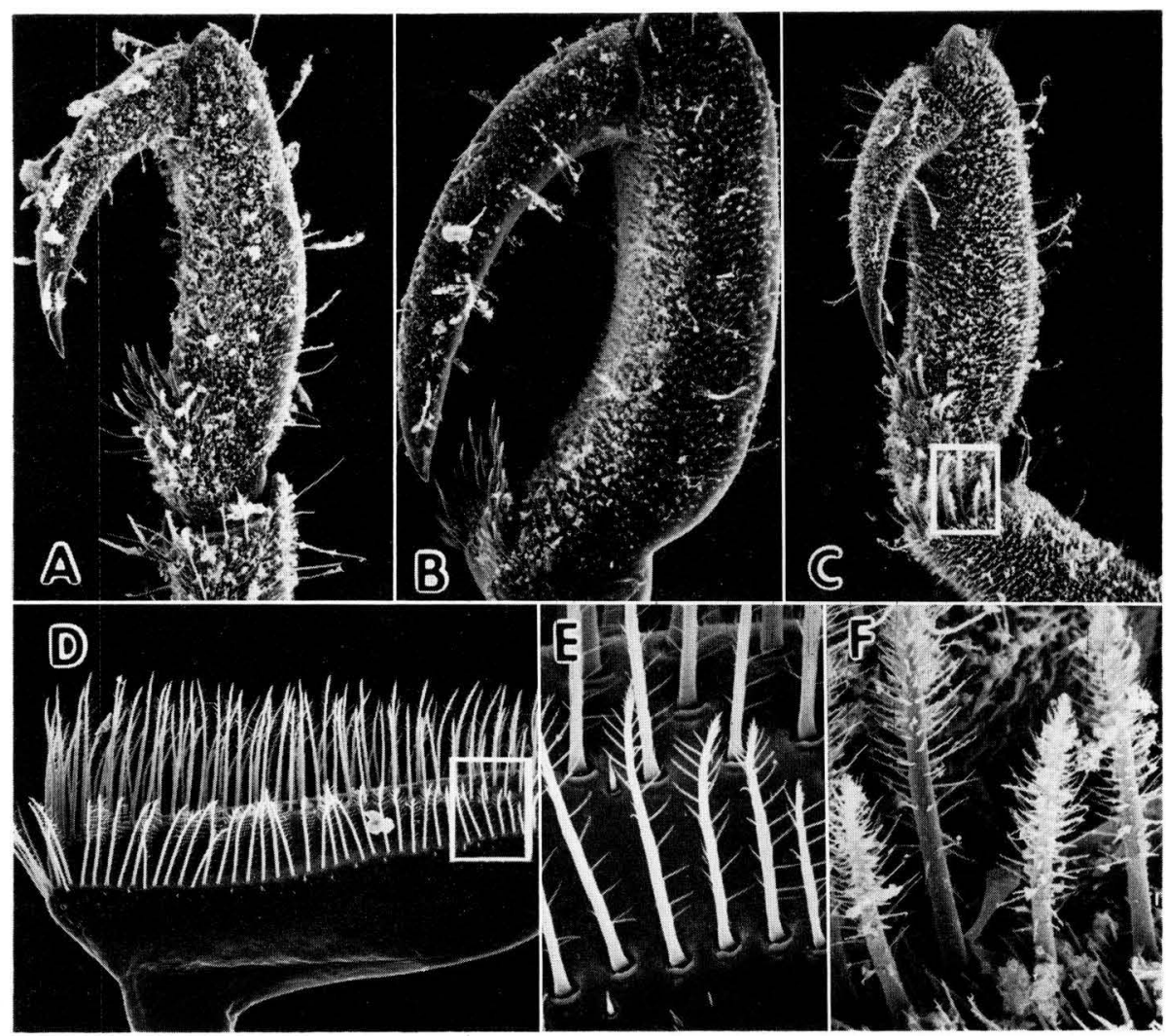

Fig. 24. Scanning electron micrographs of dorippids, first crab stage. A, Dorippe frascone; C, F, Nobilum japonicum japonicum; B, D, E, Paradorippe granulata. A, fourth pereiopod $(\times 100)$; B, fifth pereiopod $(\times 150)$; C, fifth pereiopod $(\times 100)$; D, third maxilliped, proximal portion of epipod $(\times 150)$; E, detail of setae indicated in $\mathrm{D}(\times 750) ; \mathrm{F}$, detail of apical setae of carpus, indicated in $\mathrm{G}(\times 750)$.

the first crab stages obtained (and obviously its precedent megalopa) as belonging to the genus Nobilum. For over ca. 150 years, carcinologists have been recognizing only three species of dorippids (subfamily Dorippinae) in Japan. Only one of these belongs to the genus Nobilum (formerly Neodorippe), so that during the course of this study, I was inclined to believe that megalopas obtained could be easily assigned to Nobilum japonicum japonicum. However, Manning \& Holthuis (1986) recently described Nobilum arachnoides as a new species of the genus, based upon old material obtained in 1875 from the Inland Sea of Japan. The descriptions of the megalopa and first crab stages provisionally assigned herein to $N$. $j$. japonicum certainly belong to this genus, but whether or not the stages belong to this species is not quite fully certain, because of the second Japanese species reported by Manning \& Holthuis (1986). No postlarval stages are known for the recently described $N$. arachncides. In addition to recent studies on the taxonomic status of the family and subfamilies of Dorippidae (Sakai, 1976; Manning \& Holthuis, 1981, 1986: Miyake, 1983; Holthuis \& Manning, 
Table 1. Main differences on megalopal characters for the dorippids species observed in this study (Invariable characters have been omitted).

\begin{tabular}{|c|c|c|c|}
\hline Characters & D. frascone & $N \cdot j \cdot$ japonicum & $P \cdot$ gramulata \\
\hline Carapace: & $\begin{array}{c}\text { setose, } 2-3 \text { small } \\
\text { protuberances } \\
\text { mid-dorsally }\end{array}$ & $\begin{array}{c}\text { profusely tomentose, } \\
\text { no tubercles or } \\
\text { protuberances }\end{array}$ & $\begin{array}{l}\text { finely spinulate, no } \\
\text { protuberances }\end{array}$ \\
\hline \multicolumn{4}{|l|}{ Antenna: } \\
\hline $\begin{array}{l}\text { flagellum (segm.) } \\
\text { peduncle }\end{array}$ & $\begin{array}{l}11, \text { no tomentose } \\
\text { no tomentose }\end{array}$ & $\begin{array}{l}\text { 14, all tomentose } \\
\text { tomentose }\end{array}$ & $\begin{array}{l}\text { 10, no tomentose } \\
\text { tomentose }\end{array}$ \\
\hline \multicolumn{4}{|l|}{ Mandible, palp: } \\
\hline (distal setae) & 11 & $11-13$ & 11 \\
\hline \multicolumn{4}{|l|}{ Maxillule, setation: } \\
\hline endopod & 7 (bas) +5 (dist) & 2 (bas) +2 (dist) & 2 (bas) +2 (dist) \\
\hline basal endite & 35 & $29-31$ & 29 \\
\hline coxal endite & 15 & $15-16$ & 15 \\
\hline \multicolumn{4}{|l|}{ Maxilla, setation: } \\
\hline endopod & 0 (bas) +5 (dist) & 3 (bas) +2 (dist) & 3 (bas) +2 (dist) \\
\hline basal endite & 25 & 16 & $20-22$ \\
\hline coxal endite & 3 & 2 & 2 \\
\hline scaphognathite & $105-108$ & $110-113$ & $137--140$ \\
\hline \multicolumn{4}{|l|}{ 2nd Mxpd, exopod: } \\
\hline $\begin{array}{l}\text { outer setation of } \\
\text { basal segment }\end{array}$ & 3 & $4-5$ & $2-3$ \\
\hline \multicolumn{4}{|l|}{ 3rd Mxpd, setation: } \\
\hline epipod & $32-33$ & 26 & $21-22$ \\
\hline Telson & almost as long as broad & (not observed) & clearly longer than broad \\
\hline \multicolumn{4}{|l|}{ Chelipeds, fingers: } \\
\hline inner borders & toothed & strongly toothed & indistinctly toothed \\
\hline
\end{tabular}

1985), a new revision of the Dorippidae s. s. (=the old genus Dorippe) is in preparation (Dr. Holthuis, pers. comm.).

Comparisons between the three dorippid species.

As in the adults, the postlarval stages of $N . j$. japonicum and $P$. granulata are morphologically more similar to each other than to the remaining species, $D$. frascone (see Tables 1 and 2). The tubercles on the dorsal surface of the carapace of the latter species appear in the megalopa and in the first crab stages as discrete, longitudinally directed elevations (tubercles). However, a more distinct character to separate $D$. frascone from the other two species is the great development of the inner suborbital projection (tooth), emerging ventro-anteriorly from the base of the antenna and eye stalk, which in adults reaches beyond the frontal margin, as seen in dorsal view (cf. Fig. 20A, a). These projections are as long as the anterolateral tooth of the carapace in the first crab stage of $D$. frascone (Fig. 3D-F), while they are short in Nobilum (Fig. 8E), and almost rudimentary in P. granulata (Fig. 15G). The distinct epibranchial tooth on either side of the carapace which distinguishes the adults 
of the genera Phyllodorippe, Medorippe and Dorippe (Manning \& Holthuis, 1981, p. 29) from other dorippids was absent in the megalopa and first crab stages of $D$. frascone. This character, together with the prominent and numerous dorsal tubercles (cf. Fig. 20A) probably appear in the successive young crab stages. In all of the three studied species, the differences in the morphology and setation of the chelipeds in the adults (see Fig. 21 B, E, H) first appear moderately in the megalopa, becoming more apparent in the first crab.

On the other hand, the armature and morphology of the zoeal telson clearly distinguish the zoeal stages of $D$. frascone and $P$. granulata. Unfortunately, no exuviae of later zoeas of Nobilum were obtained in the laboratory. In $D$. frascone, the lateral spines are rather short, situated almost at the middle of the length of the peduncle of telson, and the fine spinulation evenly covers the spines and the telson furcae

Table 2. Main differences on 1st crab characters for the dorippid species observed in this study (Invariable characters have been omitted).

\begin{tabular}{|c|c|c|c|}
\hline Characters & D. frascone & $N \cdot j \cdot$ japonicum & $P$. granulata \\
\hline \multicolumn{4}{|l|}{ Antenna, flagellum: } \\
\hline No of segments & 16 & 19 & 10 \\
\hline \multicolumn{4}{|l|}{ Mandible, palp: } \\
\hline (distal setac) & 15 & 14 & $16-17$ \\
\hline \multicolumn{4}{|l|}{ Maxillule, setation: } \\
\hline endopod & 6 (bas) +2 (dist) & 2 (bas) +2 (dist) & 2 (bas) +2 (dist) \\
\hline basal endite & 40 & 35 & $30-32$ \\
\hline coxal endite & $18-19$ & 17 & $16-17$ \\
\hline \multicolumn{4}{|l|}{ Maxilla, setation: } \\
\hline endopod & 4 (bas) +6 (dist) & 3 (bas $)+3($ dist $)$ & 3 (bas) $+(2-3)($ dist $)$ \\
\hline basal endite & 30 & $19-21$ & 23 \\
\hline coxal endite & $3-4$ & 2 & 2 \\
\hline scaphognathite & $148-150$ & numerous & $225--227$ \\
\hline \multicolumn{4}{|l|}{ 1st Mxpd: } \\
\hline epipod setation & 25 & $26-27$ & 13 \\
\hline \multicolumn{4}{|l|}{ 2nd Mxpd, setation: } \\
\hline $\begin{array}{l}\text { exopod, outer } \\
\text { margin of basal } \\
\text { segment }\end{array}$ & 4 & $10-11$ & $20-21$ \\
\hline epipod & 10 & $7-8$ & $8-9$ \\
\hline \multicolumn{4}{|l|}{ 3rd Mxpd: } \\
\hline epipod setation & $38-40$ & $50-53$ & $41-43$ \\
\hline \multicolumn{4}{|l|}{ Pereiopods 2-3: } \\
\hline dactylus & sparsely setose & $\begin{array}{l}\text { setose along outer margin } \\
\text { and along } 1 / 2 \text { of inner } \\
\text { margin }\end{array}$ & sparsely setose \\
\hline \multicolumn{4}{|l|}{ Sternum: } \\
\hline $\begin{array}{l}\text { tip of endopod of } \\
\text { the Ist Mxpd. }\end{array}$ & $\begin{array}{l}\text { not reaching the } \\
\text { frontal notch }\end{array}$ & $\begin{array}{l}\text { slightly reaching } \\
\text { the frontal notch }\end{array}$ & $\begin{array}{l}\text { reaching beyond the } \\
\text { frontal notch }\end{array}$ \\
\hline suborb. tooth & greatly developed & short & vestigial \\
\hline
\end{tabular}

bas =basal; $\quad$ dist=distal; $\operatorname{mxpd}=$ maxilliped; segm=segment $; \quad$ suborb.=suborbital. 
(Figs 2G, 22A). This was not noted by Terada (1981) for zocas of the same species. In P. granulata the lateral spines are longer, emerging nearer to the base of the telson, and the fine spinulation covers the spines and furcae, but there is a glabrous area between them (Figs 13I ; 23D, E). This pattern in the fine spinulation or tomentum was adequately figured by Kurata (1964, p. 73) for his zoea III and IV stages of $P$. granulata. SEM observations on the present zoeas revealed that in addition to the fine spinules (those observable by light microscopy), secondary, paired rows of more minute spinules are placed between the longer spinules (Fig. 22C, F); these are absent in the proximal area of the furcae but abundant toward the distal one-third. The morphological resemblances in the megalopa and first crab stages between $P$. granulata and Nobilum should also suggest (presumably) that the zoeas of Nobilum exhibit a pattern of telsonal spinulation more similar to that of $P$. granulata than to that of $D$. frascone.

\section{Summary}

1. Later zoeal stages of Dorippe frascone and of Paradorippe granulata are characterized by a distinctive and remarkable development of both rostral and posterior carapace spines, as well as by a rather simple telson, with slender and spinulose furcae.

2. The megalopal stage of the two above mentioned species, and that of Nobilum japonicum japonicum is distinctive in having long pereiopods II and III, and a highly modified propodus-dactylus in pereiopods IV and $\mathrm{V}$, which are used precociously for carrying objects dorsally. This is the first time that dorippid megalopas are observed in the laboratory.

3. The first crab is similar to the megalopa, and a combination of characters allows separating this stage among the three species herein studied. Some characters of the adults already appear in the first crab, although not markedly.

4. Judging by the morphologies of zoeas, postlarvae and adults, Nobilum japonicum and Paradorippe granulata seem to be more closely related to each other than to Dorippe frascone.

\section{Acknowledgements}

My thanks are due to Prof. F. Iwata (Hokkaido University) for all facilities provided to finish this study, which was initiated at the Usa mar. biol. Inst., Kochi University. I also thank Dr. K. Konishi (Hokkaido University) and Dr. M. Takeda (National Science Museum, Tokyo) who have generously allowed me to examine dorippid adult forms. I an particularly grateful to Dr. L.B. Holthuis (Rijksmuseum van Natuurlijke Historie, Netherlands) and Dr. J.W. Martin (Florida State University) who critically read the manuscript and improved it with many helpful suggestions.

\section{References}

Aikawa, H. 1933. On larval forms of some Brachyura. Paper II. A note on indeterminable zoeas. Rec. occanogr. Wks. Japan, 5: 124-254.

- 1937. Further notes on branchyuran larvae. Ibid., 9: 87-162. 
Bourdillon-Casanova, L. 1960. Le meroplancton du Golfe de Marseille: les larves de crustacés décapodes. Recl. Trav. Stat. mar. Endoume, 30: 1-286.

Fagetti, E. 1960. Primer estadio larval de cuatro crustáceos braquiuros de la Bahía de Valparaíso. Rev. Biol. mar., 10: 143-154.

Felder, D.L., J.W. Martin \& J.G. Goy. 1985. Patterns in early postlarval development of decapods. Pp. 163-225 In: Wenner, A.M. (ed.), Larval Growth, Grustacean Issues, Vol. 2. A.A. Balkema, Rotterdam.

Gilet, R. 1952. Métazoé de Dorippe lanata (Linne) et sa Mégalope. Vie Milieu, 3: 415-420.

Hashmi, S.S. 1970. The brachyuran larvae of west Pakistan hatched in the laboratory (Decapod, Crustacea). Pak. J. Zool., 2: 81-93.

Hong, S.Y. 1976. Zocal stages of Orithyia sinica (Linnaeus) (Decapoda, Calappidae) reared in the laboratory. Publ. Inst. mar. Sci., natn. Univ. Busan, 9: 17-23.

Holthuis, L.B. \& R.B. Manning. 1985. Neodorippe Serène \& Romimohtarto, 1969 (Crustacea, Decapoda) : Proposed designation of a type species. Z.N. (S.) 2467. Bull. zool. Nom., 42, pt. 3: 304305.

Kurata, H. 1964. Larvae of the decapod Crustacea of Hokkaido. 8. Dorippidae (Brachyura). Bull. Hokkaido reg. Fish. Res. Lab., 29: 71-74. (In Japanese, with English summary)

Manning, R.B. \& L.B. Holthuis 1981. West African branchyuran crabs (Crustacea: Decapoda). Smithsonian Contrib. Zool., 306: 1-379.

- 1986. Preliminary descriptions of four new species of dorippid crabs from the Indo-West Pacific region (Crustacea: Decapoda: Brachyura). Proc. biol. Soc. Wash., 99: 363 -365.

Miyake, S. 1983. Japanese crustacean decapods and stomatopods in color. Vol. II Brachyura (Crabs). Pp. 1-277. Hoikusha, Osaka. (In Japanese)

Quintana, R. 1986. On the early post-larval stages of some leucosiid crabs from Tosa Bay, Japan (Decapoda: Brachyura, Leucosiidae). J. Fac. Sci. Hokkaido Univ., Ser. VI, Zool., 24: 227-266.

Raja Bai, K.G. 1959. Studies on the larval development of Brachyura III. Development of Calappa lophos (Herbst) and Matuta lunaris Forskål (Crustacea: Brachyura). J. zool. Soc. India, 2: 6572.

Rice, A.L. 1980a. Crab zoeal morphology and its bearing on the classification of the Brachyura. Trans. zool. Soc. Lond., 35: 271-424.

- 1980b. The first zoeal stage of Ebalia nux A. Milne Edwards 1883, with a discussion of the zoeal characters of the Leucosiidae (Crustacea, Decapoda, Brachyura). J. nat. Hist., 14: $331-337$.

Sakai, T. 1976. Crabs of Japan and adjacent seas. Pp. 1-773 (25I Plates in separate volume). Kodansha, Tokyo.

Salman, D.S. 1982. Observations on the larvae of North European crabs of the genus Ebalia (Brachyura, Leucosiidae). Crustaceana, 42: 256-269.

Terada, M. 1981. Zoeal development of three species of crab in the subfamily Dorippinae. Zool. Mag., Tokyo, 90: 21-32.

Wear, R.G. \& E.J. Batham 1975. Larvae of the deep sea crab Cymonomus bathamae Dell, 1971 (Decapoda, Dorippidae) with observations on larval affinities of the Tymolinae. Crustaceana, 28: $113-120$.

Wicksten, M.K. 1982. Behaviour in Clythrocerus planus (Rathbun, 1900) (Brachyura, Dorippidae). Crustaceana, 43: 306-308.

- 1986. Garrying behavior in brachyuran crabs. J. crust. Biol., 6: 364-369. 